\title{
Can't We All Get Along? The Case for a Workable Patent Model
}

Srividhya Ragavan

Texas A\&M University School of Law, ragavan.sri@law.tamu.edu

Follow this and additional works at: https://scholarship.law.tamu.edu/facscholar

Part of the Health Law and Policy Commons, Intellectual Property Law Commons, and the International Trade Law Commons

\section{Recommended Citation}

Srividhya Ragavan, Can't We All Get Along? The Case for a Workable Patent Model, 35 Ariz. St. L.J. 117 (2003).

Available at: https://scholarship.law.tamu.edu/facscholar/492

This Article is brought to you for free and open access by Texas A\&M Law Scholarship. It has been accepted for inclusion in Faculty Scholarship by an authorized administrator of Texas A\&M Law Scholarship. For more information, please contact aretteen@law.tamu.edu. 


\title{
CAN'T We All Get Along? The Case for a Workable Patent Model
}

\author{
Srividhya Ragavan*
}

\section{INTRODUCTION}

America and Canada made significant moves during the anthrax crisis to ensure access to drugs by restricting the rights of patent holders. The prevailing economic slump in the United States has resulted in policies furthering generic drugs to the detriment of the patent holders. Issues of economic crisis and public health that moved America towards the generic industry are prevalent in the developing nations in a magnified manner. Yet tighter patent regimes are advocated for these nations. The policies that developed nations advocate have the inherent danger of extinguishing the dream of a global trade regime.

Countries traditionally carve patent policies to complement industrialization and trade by encouraging invention. The roots of patent policies in the developed nations can be traced to the post-World War II era when the focus shifted from war to trade. ${ }^{1}$ Countries expanded beyond national boundaries seeking superior trade and economic positions by

* Associate Professor, University of Oklahoma Law Center, Norman, Oklahoma; Visiting Faculty, National Academy for Legal Scholarship \& Research, Hyderabad, India; formerly Faculty, Center for Intellectual Property Rights and Advocacy at the National Law School of India University, Bangalore, India; and Texas Instruments Visiting Scholar, University of Washington, Seattle, Washington (Summer 2000). Currently the author is pursuing an SJD degree at the George Washington University Law School specializing in patent law. The author would like to thank Professor Martin Adelman for his encouragement and guidance and his expertise in issues related to international patent law. Additionally, the author would like to extend a very special thanks to Professor Jay Kesan for offering insightful comments and guidance and for helping to sculpt thought fragments into a logical paper. The title of this paper is based on Professor Kesan's suggestions in structuring the work. The author also wishes to thank Dean Susan Karamanian, Professor Carlos Correa, Professor Ruth Gana Okediji, Professor Samuel Oddi, and Ms. Shraddha Upadhyaya for offering very helpful comments at various stages of this paper.

1. Martin J. Adelman et al., Cases and Materials on Patent law $\S 1.3(\mathrm{e})$, at 23 (1998). 
investing and inventing. ${ }^{2}$ By the end of the 1800 s, nations realized that poor patent policies could affect trade. ${ }^{3}$

This realization laid the foundation for intellectual property policies. ${ }^{4}$ The importance of international intellectual property policies was highlighted when developed nations noted that the developing nations distorted international trade. ${ }^{5}$ Industries from developed nations hesitated to invest in developing nations due to those nations' poor patent policies. ${ }^{6}$ Policy experts canvassed for immediate and better intellectual property protection, ${ }^{7}$ resulting in the birth of the philosophy leading to the Trade Related Aspects of Intellectual Property Rights ("TRIPS") 8 agreement, powered by the .World Trade Organization ("WTO"). ${ }^{9}$ This agreement was the first step to facilitate free trade by requiring all nations to fall within a uniform trade structure. ${ }^{10}$ The developing countries objected to the patent

2. Id.

3. Id. $\S 1.3(\mathrm{e})(2)$, at 26 . Currently, different standards determine whether a country is regarded as "developing." The United Nations, the International Monetary Fund, and the International Bank for Reconstruction and Development all use relatively different yardsticks in making this determination. The term "developing nations" in this paper denotes the least developed nations, such as Somalia, Ethiopia, and Tanzania.

4. See Berne Convention for the Protection of Literary and Artistic Works, Sept. 9, 1886, 25 U.S.T. 1341, 828 U.N.T.S. 221, 223 (last revised July 24, 1971) (hereinafter Berne Convention]; Paris Convention for the Protection of Industrial Property, Mar. 20, 1883, 21 U.S.T. 1583, 1630, 828 U.N.T.S. 305, 307 (last revised July 14, 1967) [hereinafter Paris Convention].

5. See Robert Pechman, Seeking Multilateral Protection for Intellectual Property: The United States "TRIPs" over Special 301, 7 MinN. J. Global TRADE 179, 181-82 (1998).

6. Id. See also Anthony D. Sabatelli, Impediments to Global Patent Law Harmonization, 22 N. KY. L. REV. 579, 618-19 (1995) (discussing the benefits of strong intellectual property rights); David Tomar, A Look into the WTO Pharmaceutical Patent Dispute Between the United States and India, 17 WIS. INT'L L.J. 579 (1999) (discussing India's resistance of the U.S. to bring about a patent amendment).

7. See Sabatelli, supra note 6, at 619; Evelyn Su, The Winners and Losers: The Agreement on Trade-Related Aspects of Intellectual Property Rights and its Effects on Developing Countries, 23 Hous. J. INT'L L. 169, 177-178 (2000); see also Stefan Kirchanski, Protection of the U.S. Patent Rights in Developing Countries: U.S. Efforts to Enforce Pharmaceutical Patents in Thailand, 16 LOY. L.A. INT'L \& COMP. L. REV 569, 571 (1994) (noting that developed countries believe a good patent system leads to economic growth); Robert M. Sherwood, Intellectual Property for Latin America: How Soon Will it Work?, 4 NAFTA L. \& BUS. REV. AM. 77, 80 (1998), available at http://ns.kreative.net/ipbenefits/ iplatam/right.htm (last visited Jan. 24, 2003) (discussing the stimulation of intellectual efforts).

8. Agreement on Trade-Related Aspects of Intellectual Property Rights, Apr. 15, 1994, Marrakech Agreement Establishing the World Trade Organization, Annex 1C, LEGAL INSTRUMENTS-RESULTS OF THE URUGUAY ROUND vol. 31, 33 I.L.M. 81 (1994) [hereinafter TRIPS Agreement].

9. Id.

10. Id. The Preamble indicates a "desir[e] to reduce distortions and impediments to international trade ... [by] promot[ing] . . . adequate protection of intellectual property rights," 
policy in TRIPS, resulting in an escalating tension between the developing and developed nations. ${ }^{11}$

Today, the economies of developing countries are destabilized by unemployment, poverty, and political and financial instability. ${ }^{12}$ These countries lack the basic infrastructure and the economic viability to establish and support a sophisticated patent policy. This unfavorable economic circumstance is an impediment to successful enforcement of TRIPS-like patent policies. ${ }^{13}$ Naturally, developing nations need to be wary of the TRIPS patent regime, similar to the manner in which developed nations mistrusted patents during the Great Depression and the World Wars. ${ }^{14}$ A completely different set of economic circumstances enabled the genesis of a patent policy in the developed nations. ${ }^{15}$ Forgetting those circumstances, the developed nations now mistakenly believe that if counterfeit products are curtailed, people will be forced to buy patented products. Ignoring the individual difficulties of implementing nations is a strategic mistake that can ultimately harm developed nations.

Undeniably, all countries should fall within the trade-oriented system of the post-World Wars era economies. A good patent policy is a fundamental requirement for movement toward a trade era. However, it is questionable whether TRIPS is the best mechanism for the developing nations to join the trade and intellectual property fraternity. Developed nations will be adversely affected if developing nations subscribe to the TRIPS patent policy without building a supporting infrastructure. The consequences may potentially affect the post world war trade structure ("trade structure"). This article discusses the impact of the current WTO patent policy on developed nations and on the trade structure and distinguishes itself from other

and by promoting "standards and principles [for the] availability, scope and use of trade-related intellectual property rights." $I d$. at 84 .

11. Id. The Preamble acknowledges the underlying tension between developing and developed nations and "emphasize[s] the importance of reducing tensions by reaching strengthened commitments." Id.

12. See generally Paul Krugman, The Return of Depression Economics ix-xi, 155 (1999) (analyzing the world economic crisis originating in East Asia in 1997 as the return of depression economics).

13. See Ruth Gana, Prospects for Developing Countries Under the TRIPs Agreement, 29 VAnd. J. TRansnat'L L. 735, 770-71 (1996). Professor Gana contends that "it would be wishful to assume that enforcement of the TRIPs Agreement will take place without some form of internal resistance, however this is manifested." Id. She argues that developing countries need to know "how to walk before [they can start] leap[ing]," which she contends is what is expected under the TRIPS Agreement. Id.

14. ADELMAN ET AL., supra note $1, \S 1.3(\mathrm{e})$, at 23.

15. See infra Parts II.A-B. 
contributions to this subject by focusing on the impact on developed nations.

Parts II and III of this paper lay the theoretical foundations for the detailed analysis which follows in parts IV and V. Part II traces the historic circumstances fostering the development of patent policies in the developed and developing nations. An understanding of the circumstances leading to a specified path for patent policies in developed and developing nations facilitates a fuller appreciation of part III, which discusses the pre-TRIPS patent legislation of developing countries. India is used as a case study in part III to discuss various areas where developing countries display unique issues. The resistance of the Indian government to implement TRIPS and the pressure under which amendments were made to the Indian patent legislation to harmonize it with TRIPS is also discussed. This part complements the discussions on the resistance of the Indians detailed in part V.

Part IV discusses four issues that make the expectations from developing nations to ease into a patent regime impractical. Even assuming developing countries amend the patent legislation, implementation will be impossible. Part IV further argues that developed nations chose policy options strikingly similar to the pre-TRIPS patent policies of developing nations when faced with similar economic and social issues.

Part V demonstrates how reactions of people in developing nations to TRIPS patent policy will result in adverse consequences to developed nations. Developed nations have already garnered enormous monetary and strategic losses by attempting to establish the TRIPS patent policy in the developing world. Continuing this strategy could affect the world trade structure and may be detrimental to the developed nations.

This effort is intended to highlight factors that need to be accounted for in order to fashion a realistic patent policy that is workable in developing countries. The division between the developed and developing nations is not about ideology, but about practicability. The impractical assessment of the various factors led to the failure of the patent policy in critical areas. TRIPS lacks sensitivity to local needs and realities. It neither takes account of, nor provides any solutions to, issues that developing countries are bound to face in implementing the treaty. Even the rich, patent friendly nations have considered patent restricting options under economic crisis or under threat to public health. Given this, developed nations posit a strategically losing argument in forcing impoverished nations swamped by diseases to embrace TRIPS. Developing nations will be unable to mirror patent policies of developed nations without compromising on research and development and negatively affecting the global trade regime. 


\section{THE DEVELOPMENT}

To fully appreciate patent policies, it is important to understand how they evolved historically. Economic gains were the main motive for the development of patent policies. Whenever an economic or public health crisis emerged, the patent policies were subjected to state power. The development of patent policies in the developed nations and the emergence of the international patent policy are traced in the first two sections. The last section, Patent Fallacy in Developing Countries, discusses the economic realities that fostered the development of a patent policy in the developing nations.

\section{A. Patent Policy}

Patent laws had a partial genesis in Venice in the early 1300 s. $^{16}$ In 1323 , a German milling engineer, who undertook to build grain mills to satisfy the storage needs of all of Venice, was granted the first known privilege for approximately 80 ducats. $^{17}$ The first law providing the grant of exclusive rights for a limited period as an economic policy to inventors evolved in Venice in $1474 .^{18}$ In 1488 , the Statuto Mineraria vested monopoly rights to develop local industries. ${ }^{19}$ During this period, the Venetian economy was deteriorating because of a long war between Venice and Turkey. ${ }^{20}$ Venice had lost its trading empire in the Eastern Mediterranean. ${ }^{21}$ The Statuto Mineraria was drafted by Venice to focus on economic development. ${ }^{22}$ The Venetian system influenced the British, who pioneered the development of early patent laws. ${ }^{23}$

16. ADELMAN ET AL., supra note $1, \S 1.3(\mathrm{~b})(1)$, at 9 .

17. Id. at 10. The ducat was the prevailing currency of the time.

18. Id. at 10-11.

19. Id.

20. Ladas \& Parry, A Brief History of Patent Law of the United States, at http://www.ladas.com/Patents/USPatentHistory.html (last visited Jan. 23, 2003); see also Edward C. Walterscheid, The Early Evolution of the United States Patent Law: Antecedents (Part l), 76 J. Pat. \& Trademark Off. SoC'Y 697, 705-06 (1994) (discussing monopoly grants to encourage new trade and industry).

21. Ladas \& Parry, supra note 20; see also Walterscheid, supra note 20, at 710.

22. ADELMAN ET AL., supra note 1, at 11; Ladas \& Parry, supra note 20 (discussing the history of early Venetian patent law).

23. Walterscheid, supra note 20, at 706; see also Thomas M. Meshbesher, The Role of History in Comparative Patent Law, 78 J. PAT. \& TRAdEMARK OfF. SOC'Y 594 (1996) (discussing origins of European patent law). 


\section{Patent Development in the United Kingdom}

In England, patent law developed in the form of the crown's prerogative to issue letters patent. ${ }^{24}$ "Letters patent . . bestow[ed] privileges upon individuals in furtherance of royal policies." 25 Notably, these privileges were designed not to increase trade, ${ }^{26}$ but to "entic[e] tradesmen and industrialists to [manufacture] in England." 27 King Edward III issued letters patent to protect foreigners coming to England for the purpose of training subjects in various trades. ${ }^{28}$ Patents were granted to lure foreign industries into England, thereby sustaining local industries and enabling Britain to become self-sufficient. ${ }^{29}$ Sir Walterscheid, in his extensive work, asserted that Queen Elizabeth I made an effort "to stimulate domestic production of both raw materials and a wide variety. of manufactured goods previously imported from abroad" by granting patents. ${ }^{30}$

However, creating monopoly rights in this way violated the principles of the common law. ${ }^{31}$ The State restrained trade in the best interest of the nation, an action similar to the compulsory license provisions of today. ${ }^{32}$ In 1623, the Statute of Monopolies was codified. ${ }^{33}$ This statute granted statutory recognition and legal status for patents. ${ }^{34}$ In 1752 , patents in England advanced from being a royal prerogative to a subject matter adjudicated by common law courts. ${ }^{35}$ The specification requirement evolved in England during this time. ${ }^{36}$ Various changes in the procedure for obtaining patents were introduced in 1852,1883 , and 1888 , although the

24. Adam Mossoff, Rethinking the Development of Patents: An Intellectual History 1550 1800, 52 HASTINGS L.J. 1255, 1259 (2001).

25. Id.

26. Id. at 1259 n. 15 .

27. Id. at 1259; see also Walterscheid, supra note 20 , at $700-01$.

28. Christine Macleod, Inventing the industrial Revolution: The English PATENT SYSTEM, 10, 1660-1800 (1988); see also Mossoff, supra note 24, at 1259 n.16.

29. Mossoff, supra note 24, at 1261-62.

30. Id. at 1261 (quoting Edward C. Walterscheid, The Early Evolution of the United States Patent Law: Antecedents (Part 2), 76 J. PAT. \& TRADEMARK OfF. SOC'Y 849, 855 (1994)).

31. See id. at 1262.

32. See Jacob I. Corré, The Argument, Decision, and Reports of Darcy v. Allen, 45 EMORY L.J. 1261, 1324-25 (1996) (analyzing the judgment in Darcy v. Allen, 77 Eng. Rep. 1260 (1603))

33. Id. at 1271. Starting with the famous case of Darcy $v$. Allen, Parliament and the Crown were constantly at loggerheads over the grant of monopoly patents. Id. at 1267-70. Conflicts continued until the early 1620s. Id. at 1270. This resulted in Parliament passing the Statute of Monopolies in 1623. Id. at 1271.

34. Id. at 1272 .

35. Id at 1286 .

36. Id. at 1289-90. 
common law rules still prevailed. ${ }^{37}$ It was not until the Patents and Designs Act of 1932 that statutory grounds were first introduced. ${ }^{38}$ The Patents Act of 1949 abolished the common-law grounds, leaving the grant of patents to be governed exclusively by statutory grounds. ${ }^{39}$ In 1977 , British patents legislation underwent another major amendment. ${ }^{40}$ This led to the creation of the patent courts. ${ }^{41}$ Currently, the Patents Act of 1977, read with the Patents Rules of 1995 , regulates the substantive law and practice of patents in the U.K. ${ }^{42}$

\section{Patents in the United States}

Both policymakers and the Supreme Court punctuated the development of patent policy in the United States with objections. The origins of the American patent system can be traced to $1641,{ }^{43}$ yet the right to a patent was not introduced until the first draft of the Constitution in $1787^{44}$ Following this, the Patents Act was introduced in 1790, and was revised in $1793 .^{45}$ Thomas Jefferson, the first Secretary of State and a strong believer in the patent system, crafted the amendments to reiterate the importance of a

37. William Aldous et al., Terrell on the Law of Patents 5 (1982).

38. David L. Cohen, Comment, Article 69 and European Patent Integration, 92 Nw. U. L. REV. 1082, 1098 (1998) (discussing modern British patent law).

39. Id.

40. R.G.C. JENKINS \& Co., Patents Act 1977, at http://www.Jenkinsip.com/patlaw/index.htm (last visited Apr. 20, 2003). Most of the legislation came into operation on June 1, 1978. Id.

41. The 1977 statute was divided into three parts. The first part, domestic patents, was addressed under the title "New Domestic Law." The second part detailed the obligations under international conventions and the final part dealt with the creation of the patent court. R.G.C. JENKINS \& CO., Patents Act 1977, at http://www.Jenkins-ip.com/patlaw/index.htm (last visited Apr. 20, 2003).

42. See United Kingdom Statutory Instrument 1995 No. 2093, as amended. The act and the rules are to be read with Copyright, Designs and Patents Act, 1988, and the European Communities Act, 1972. UK Patent Law, Introduction, supra note 40.

43. ADELMAN ET AL., supra note $1, \S 1.3(\mathrm{c})$, at 13 . The history of American patents extends much further than the two hundred years since the Act of 1790. Nine of the thirteen colonies of America granted rewards for inventors, although not all of them were similar to modern-day patents. Id.

44. Id. $\S 1.3(\mathrm{c})(3)$, at 17 . The first draft of the Constitution was introduced as the Virginia Plan in 1787. Id. Charles Pinckney of the South Carolina Legislature proposed exclusive rights for inventive activity. This was recommended to the Committee on Detail. Id. Pinckney also served on the Committee on Detail. Thus, Pinckney became the source for the introduction of the Patent Clause into the U.S. Constitution. Id.

45. Id. at 19 . 
good patent policy. ${ }^{46}$. Despite Jefferson's encouragement, the depression era beginning in 1873 resulted in a vigorous distrust of patents. ${ }^{47}$ Even the Supreme Court construed patents as antitrust violations in several cases. ${ }^{48}$ At the end of World War II in 1945, the United States gained world economic leadership. ${ }^{49}$ Trade and commerce surged in the $1950 \mathrm{~s}^{50}$ Consequently, patent reform was contemplated for the first time since $1873 .^{51}$ This resulted in the enactment of the lifeline of patents in the United States in the form of the Patents Act of $1952 .{ }^{52}$

However, the enactment of the 1952 legislation did not solidify the patent system. Instead, the subjectivity in the legislation contributed to another decade of confusion in patent law. ${ }^{53}$ The Supreme Court attempted to cement the law through "The Trilogy" ${ }^{34}$ cases in $1966 .{ }^{55}$ The subjectivity in the legislation was replaced by an objective test for non-obviousness to decide patentability. ${ }^{56}$ The cement gave way in 1969 , causing more confusion when another Supreme Court decision articulated the synergism test. $^{57}$ Finally, in 1982, Congress passed the Federal Court Improvements Act, which established the Court of Appeals for the Federal Circuit and vested in it jurisdiction to hear patent appeals from U.S. District Courts. ${ }^{58}$

After this period, American patent policy evolved as the most dynamic in the world. The United States emerged as the forerunner in encouraging

46. See Bonito Boats, Inc. v. Thunder Craft Boats, Inc., 489 U.S. 141, 147 (1989) (citation omitted).

47. ADELMAN ET AL., supra note $1, \S 1.3(\mathrm{e})$, at 23 (maintaining that misplaced antitrust priorities and subjective inventiveness tests were the causes for mistrust of patents).

48. See, e.g., Jungersen v. Ostby \& Barton Co., 335 U.S. 560, 567-68 (1949); Cuno Eng'g Corp. v. Automatic Devices Corp., 314 U.S. 84, 90-92 (1941); Lincoln Eng'g Co. v. StewartWamer Corp., 303 U.S. 545, 552 (1938); R.M. Hollingshead Co. v. Bassick Mfg. Co., 73 F.2d 543,550 (6th Cir. 1934).

49. ADELMAN ET AL., supra note $1, \S 1.3(\mathrm{e})(1)$, at 23-24.

50. Id.

51. Id. at 24

52. Id.

53. Id.

54. Id. $\S 7.1$, at 417 (noting that the three cases were "of such importance to the patent bar that they became known merely as 'The Trilogy.").

55. See Graham v. John Deere Co., 383 U.S. 1, 12-19 (1966); United States v. Adams, 383 U.S. 39, 48-52 (1966). The third of the three cases known as "The Trilogy," Calmar Inc. v. Cook Chemical Co., was consolidated with Graham. Graham, 383 U.S. at 1.

56. ADELMAN ET AL., supra note $1, \S 1.3(\mathrm{e})(1)$, at 24 .

57. See Anderson's Black Rock, Inc. v. Pavement Salvage Co., 396 U.S. 57, 61 (1969) (explaining the "synergism" test by stating that "[a] combination of elements may result in an effect greater than the sum of the several effects taken separately").

58. See Rochelle Cooper Dreyfuss, The Federal Circuit: A Case Study in Specialized Courts, 64 N.Y.U. L. REV. 1 (1989) (appraising the role of the Court of Appeals for the Federal Circuit). 
patents in areas like chemical, ${ }^{59}$ biotechnology, ${ }^{60}$ business methods, ${ }^{61}$ software, ${ }^{62}$ and methods of medical treatment. ${ }^{63}$ Patent law has been used to commensurate industrial development such as in the biotech industry. The seminal case of Diamond v. Chakrabarty ${ }^{64}$ paved the way for biotech patents. Soon the United States became the only choice for future investment of biotech companies. The development was so vast that companies were scrambling for biotech patents. This led to several innovations and inventions in biotechnology and pharmaceuticals. ${ }^{65}$ Several European countries, including Germany and England, followed the biotech patent trend. ${ }^{66}$

The British crafted the early development of patent policies, while the Americans engineered the modern patent system. Both countries had two advantages-recognition of the importance of a good patent system coupled with the blessing of economic leadership. In spite of these advantages, it took more than a century, from the 1800 s until the mid-1900s, before a sustainable patent policy was crystallized.

\section{B. Patent Prescription}

Traditionally, the developed nations, headed by the United States, face two major concerns in international trade. The first is the lack of minimum standards enabling countries to set their own standards of intellectual

59. See, e.g., Brenner v. Manson, 383 U.S. 519, 528-36 (1966) (discussing the utility requirement in chemical patents).

60. See, e.g., Diamond v. Chakrabarty, 447 U.S. 303, 309-10 (1980) (holding that a utility patent can be granted for a human-made microorganism).

61. See, e.g., State Street Bank \& Trust, Co. v. Signature Fin. Group, Inc., 149 F.3d 1368, 1375 (Fed. Cir. 1998). This decision was reaffirmed by the Federal Circuit in AT\&T Corp. $v$. Excel Communications Inc., 172 F.3d 1352, 1356 (Fed. Cir. 1999). See also Heath W. Hoglund, Internet Patents Enter the Federal Courts, FROM THE BAR, Vol. 26 (2000) (discussing the effects of State Street Bank \& Trust on internet patents), available at http://www. hhoglund.com/FedBarl.htm (last visited Jan. 20, 2003).

62. See, e.g., Diamond v. Diehr, 450 U.S. 175, 185-87 (1981).

63. See generally Gregory F. Burch, Ethical Considerations in the Patenting of Medical Processes, 65 TEX. L. REv. 1139, 1146 (1987) (discussing the development of patent law in methods of medical treatment).

64. 447 U.S. 303, 316-17 (1980).

65. Although biotechnology patents were not the only reason, biotechnology patents were a distinguishing feature that made the United States an attractive place for biotechnology investments.

66. See generally Geertrui Van Overwalle, Patent Protection for Plants: A Comparison of American and European Approaches, 39 J.L. \& TECH. 143 (1999). The German Bundesgerichtshof (federal supreme court) was the first non-American court to deal with issues relating to biotech patents. However, it was only after the Chakrabarty decision that Europe began to encourage biotech patenting. Id. 
property protection. ${ }^{67}$ The second is the inadequacy of the international enforcement mechanism to check the deviant nations. ${ }^{68}$ The United States conventionally relied on unilateral measures such as section 1.82 of the Omnibus Trade Act of $1974,{ }^{69}$ "commonly referred to as 'Special 301,",70 for enforcement of intellectual property rights. The United States identified countries with inadequate protection of intellectual property rights and encouraged them to amend their practices. ${ }^{71}$ Those who did not amend their practices were subject to Special 301 trade sanctions. ${ }^{72}$. However, the Special 301 actions extended beyond the time frame contemplated by the United States. $^{73}$ There was no guarantee that a country coerced by trade sanctions under Special 301 would eventually enforce intellectual property rights effectively. Additionally, other General Agreement on Tariffs and Trade ("GATT") members criticized the United States for using Special 301 and violating the spirit of GATT. ${ }^{74}$ Thus, the need for an international coalition was evident.

\section{The TRIPS Agreement}

The enactment of the TRIPS agreement ${ }^{75}$ marked a renewed international effort to control worldwide deterrence in intellectual property policy. The Uruguay Round ${ }^{76}$ of the GATT resulted from efforts of "over one hundred years . . . to globally harmonize intellectual property rights.",77

67. Pechman, supra note 5, at 181-82.

68. Id.

69. Trade Act of 1974, Pub. L. No. 93-618, § 182, 88 Stat. 1978, 2041 (1975) (codified as amended at 19 U.S.C. $\S 2242(2000)$ ).

70. Pechman, supra note 5 , at 196 .

71. Id

72. Id. at 198 .

73. Id. (discussing that "none of the intellectual property cases under Special 301 [was] satisfactorily resolved [within the prescribed] time frame of six to nine month").

74. Myles Getlan, TRIPs and the Future of Section 301: A Comparative Study in Trade Dispute Resolution, 34 COLUM. J. TRANSNAT'L L. 173, 177 (1995).

75. TRIPS Agreement, supra note 8, at 1.

76. During World War II, GATT was established in 1947 to encourage non-discriminatory policies in international trade. Although GATT's role in international trade was considerable, nations felt the need for a global trade organization. Thus, the WTO was established under a multilateral agreement. The WTO is the successor to GATT, but with wider objects and functions. The multilateral trade negotiations at the Uruguay Round extended to investment, agriculture, textiles (which were previously excluded from GATT), intellectual property rights, and services. India is a member of the WTO and is obliged to follow TRIPS, which is an agreement made under the WTO. See generally World Trade Organization, http://www.wto.org (last visited Feb. 17, 2003).

77. Pechman, supra note 5 , at 180. 
"TRIPs negotiations were concluded [in 1994] as part of the Uruguay Round of GATT and the agreement establishing the WTO."78 TRIPS was adopted in $1994 .^{79}$ The TRIPS agreement was conceived to reduce international trade distortions due to infringement and misappropriation of intellectual property by developing nations. ${ }^{80}$

The TRIPS agreement establishes "minimum standards of intellectual property protection" and creates an enforcement mechanism to deal with infringement of intellectual property rights in international trade in goods. ${ }^{81}$ The basic tenet of TRIPS, detailed in articles three through five, is a principle of uniform treatment of nationals of all member states. ${ }^{82}$ The "National Treatment" clause forbids discrimination in trade between the member's own nationals and nationals of other members. ${ }^{83}$ The "MostFavoured-Nation Treatment" clause forbids discrimination between the nationals of other members in trade. ${ }^{84}$

Part II of TRIPS specifies the minimum levels of substantive norms and standards to be practiced by each member country. These norms define the subject matter to be protected, ${ }^{85}$ the minimum duration of protection, ${ }^{86}$ the rights to be conferred, ${ }^{87}$ and the permissible exceptions. ${ }^{88}$ The obligations and standards of TRIPS are read with other World Intellectual Property Organization ("WIPO") Conventions, which, in the case of patents, is the Paris Convention. ${ }^{89}$ TRIPS also provides for a dispute settlement body for multilateral intellectual property disputes. ${ }^{90}$ The dispute settlement

78. Id. at 183 .

79. TRIPS Agreement, supra note 8, at 1 .

80. M.K. Nawaz, Changing Structure of International Trade Law, WIPRO INFOTECH HANDBOOK ON INDUSTRIAL PROPERTY LAW (1997) (on file with author).

81. See J.H. Reichman, The TRIPS Agreement Comes of Age: Conflict or Cooperation with the Developing Countries?, 32 CASE W. RES. J. INT'L L. 441, 442 (2000) (discussing the positive aspects of transitioning towards TRIPS and the negative trends affecting the transition).

82. See J.H. Reichman, Compliance with the TRIPS Agreement: Introduction to a Scholarly Debate, 29 VAND. J. TRANSNAT'L L. 363, 366-74 (1996) (discussing the nature and scope of the various intellectual properties within the TRIPS agreement).

83. TRIPS Agreement supra note 8, art 3.

84. Id. art. 4.

85. Id. art. 15 .

86. Id. art. 18 .

87. Id. art. 16.

88. Id. art. 17.

89. Paris Convention, supra note 4 .

90. TRIPS agreement, supra note 8, arts. 63, 64. These articles comprise Part V, "Dispute Prevention and Settlement," the mechanism that prevents and settles disputes. The developed nations have been criticized for using the provisions to impose trade sanctions. See also Getlan, supra note 74, at 217-18 (proposing that the United States abandon the use of section 301 against GATT members since use of the TRIPS dispute resolution mechanism for an intellectual property case will yield similar results with greater benefits to the United States). 
mechanism facilitates consensus through consultation; ${ }^{11}$ if the parties do not settle, the dispute can be moved before a panel of arbitration. ${ }^{92}$ The concessions granted by TRIPS are embedded in the transitional provisions, whereby members are not obliged to comply with the TRIPS Agreement for a period of one year from the effective date of the agreement (April 1994) ${ }^{93}$ Article 65(2) allows developing countries another four years (five years in total) to comply with the provisions of the agreement. ${ }^{94}$ Article 65(4) provides the developing countries an additional five years to extend the product patent regime. ${ }^{95}$ The major advantage of the TRIPS agreement is the mandatory enforcement provisions, ${ }^{96}$ which include remedies and deterrents to prevent derogation from the agreement. ${ }^{97}$ TRIPS embodies civil and administrative procedures, ${ }^{98}$ provisional measures, ${ }^{99}$ special requirements relating to border measures, ${ }^{100}$ and criminal procedures ${ }^{101}$ applicable for right holders to effectively enforce rights.

The most controversial element of the TRIPS agreement relates to provisions on the protection of patents. ${ }^{102}$ The term of patents is twenty years from the date of the application. ${ }^{103}$ TRIPS mandates patent protection for "all fields of technology." 104 Patent protection must be provided for all inventions that are "new, involve an inventive step, and are capable of industrial application." 105 Developing nations objected that the economic conditions of these nations hindered their embracing the patent regime contemplated under TRIPS.

91. TRIPS Agreement, supra note 8, art. 64.

92. See id. Article 64 provides for dispute settlement through articles 22 and 23 of GATT, read in conjunction with the Understanding on Rules and Procedures Governing the Settlement of Disputes. Understanding on Rules and Procedures Governing the Settlement of Disputes, Apr. 15, 1994, Annex 2, Legal INSTRUMENTS-Results Of THE URUGUAY Round, 33 I.L.M. 1226, 1240 (1994) [hereinafter the Understanding]. Article 6 of the Understanding provides for the establishment of a panel at the request of the complaining party. Id. art. 6.

93. TRIPS Agreement, supra note 8, art. 65(1).

94. Id. art. 65(2).

95. Id. art. 65(4).

96. One of the major criticisms against the Paris Convention was the absence of remedial measures.

97. TRIPS Agreement, supra note 8, art. 41.

98. Id. arts. $42-49$.

99. Id. art. 50.

100. Id. art. 57.

101. Id. art. 61.

102. Shondeep Banerji, The Indian Intellectual Property Rights Regime and the TRIPS Agreement, in INTELleCtUAL PROPERTY RIGHTS IN EMERGING MARKETS 47, 57 (Clarisa Long ed., 2000).

103. TRIPS Agreement, supra note 8, art. 33.

104. Id. art. 27.

105. Id. 


\section{Patent Fallacy in Developing Countries}

India and Brazil provide useful examples to highlight how local needs shape the course for developing countries in choosing policy options. For example, when the Indian government drafted the first five-year plan to carve India's development path from 1951 through 1956, India had the "largest reservoir of . . . epidemic diseases."106 Epidemic diseases in India accounted for $5.1 \%$ of the total deaths. ${ }^{107}$ Poverty was at its peak, ${ }^{108}$ with around half of India's population living below the poverty line and unable to afford drugs. ${ }^{109}$ Consequently, life expectancy was low and the mortality rate due to diseases was high. A brief overview of Brazil highlights a similar picture where poverty and health care affect a country's patent policies.

\section{India in the Middle of a "Colonial Hangover"}

The British granted India independence in 1947 but left the plundered country suffering from poverty and poor health. India was left with the singular option of prioritizing local issues ahead of development and international trade issues. Although the East India Company opened the first window to patent law in India during the colonial regime, the laws accommodated only the needs of the colonial British Empire.

The first Indian patent law was enacted in $1856^{110}$ as a result of the recommendations of the Lord Macaulay Law Commission. ${ }^{11}$ This act and

106. Government of India, Planning Comm'n Off. Doc., First Five-Year Plan, (1951-56), (Vol. I \& II) (Jan. 2002), available at http://www.planningcommission.nic.in/ plans/planrel/fiveyr/default.html (last visited Jan. 28, 2003).

107. Id.

108. Income from industries was as low as a mere $6.6 \%$ of the gross annual national income and only $8 \%$ of the total labor force was working in the industrial establishment. Id. ch. 29.

109. Press Release, The World Bank Group, India Shows Mixed Progress in the War Against Poverty (Aug. 26, 1997), at http://www.worldbank.org/html/extdr/extme/1449.htm (last visited Jan. 28, 2003).

110. Srividhya Ragavan, Patent Amendments in India in the Wake of TRIPS, CASRIP NEWSLETTER (Univ. of Wash. Sch. of Law), Winter 2001, available at http://www.law. washington.edu/casrip/newsletter/newsv8il Ragavan.pdf (last visited Jan. 28, 2003). This Act was "modeled on the same lines as the British Patent Act of 1852." Id.

111. Lalit Sethi, Rarely Seen or Heard Law Commission's Work Has Great Impact, Press Information Bureau: Government of India (1991), at http://pib.nic.in/feature/fel 199/ f2911991.htm (last visited Mar. 17, 2003). The first Law Commission was established in 1834 under the Charter Act of 1833 and under the Chairmanship of Lord Macaulay. This commission was responsible for the codification of the Penal Code, the Criminal Procedure Code, and other legislation. The second, third, and fourth Law Commissions were constituted in 1853,1861 , and 1879 respectively. During a span of fifty years, the various commissions 
subsequent enactments ${ }^{112}$ codified the grant of "exclusive privileges" to patent owners for fourteen years. ${ }^{113}$ In 19,11, the Indian Patents and Designs Act was enacted effectively, repealing the earlier enactments. ${ }^{114}$ This Act introduced the concept of the Controller of Industrial Patents and Designs. ${ }^{115}$ However, the patent legislation lacked a clear policy to pave the way for industrial development through patents.

When India became independent in 1947, foreign multinationals controlled $80 \%$ of the Indian pharmaceutical industry, ${ }^{116}$ and hence determined the supply and availability of drugs. ${ }^{117}$ Drugs were manufactured outside of India and imported at a high cost. ${ }^{118}$ The central government imported the required drugs under the Drugs Act of $1940 .{ }^{119}$ This caused the cost of drugs in India to be among the highest in the world. ${ }^{120}$

Unable to control the expenditure on drugs, in 1948 the Indian government appointed the first committee, headed by the famous Dr. Tek Chand, to review the 1911 patent legislation. ${ }^{121}$ The committee noted that under the 1911 enactment, inventions made by any "manner of manufacture" were patentable. ${ }^{122}$ Thereafter, the committee recommended a clearer definition of a "manner of manufacture."

recommended legislation on a variety of subjects, mostly on the pattern of the English laws and adapted them to Indian conditions. The Patents Act was one such legislative act. Id.

112. See generally Ragavan supra note 110 . The 1856 patents legislation was amended in 1859 to extend "exclusive privileges" for making, selling, licensing, and using inventions in India. The Patterns and Designs Protection Act, 1872 protecting industrial designs for the first time, followed the 1856 enactment. The Protection of Inventions Act was legislated in 1883 . Finally, the 1872 and the 1883 legislations were combined and the Inventions and Designs Act, 1888 was passed. Id.

113. Id.

114. Id.

115. Id.

116. D.P. Dubey, Globalisation and its Impact on the Indian Pharmaceutical Industry, REVOLUTIONARY DEMOCRACY (April 1999), available at http://www.revolutionarydemocracy. org/rdv5n1/pharmacy.htm (last visited Jan. 28, 2003).

117. Banerji, supra note 102, at 79 .

118. Id.

119. See generally Abhijit Dey et al., Pharmaceutical Marketing in India: A Macroscopic View (Nov. 2001), at http://www.sbaer.uca.edu/research/1999/SMA/99sma151.htm (last visited Jan. 28, 2003).

120. Banerji, supra note 102, at 79. In 1961, a U.S. Senate committee headed by Senator Estes Kefauver, remarked that India ranked among the highest priced nations in the world for drugs. Id.

121. Id. at 63-64. Dr. T.B. Chand, a retired judge of the High court, chaired the committee. This committee's recommendations were incorporated in the amendments to the 1911 act that were introduced in 1950 . Id. at 67 .

122. Id. at 63 .

123. Id. at 64-65. 
ill-defined patent provisions in India enabled multinational companies to gain patent rights beyond the scope of their invention. ${ }^{124}$ The patent legislation in India was amended in $1950 .^{125}$ Although the recommendations of the committee were incorporated in the amendments to the patent legislation, no substantial changes resulted in the functioning of the patent system. ${ }^{126}$

\section{a. Limiting Factors of a Patent Solution}

The Indian government took two significant steps to ensure accessibility of medication to the poor. First, the government entered into an agreement with United Nations International Children's Emergency Fund ("UNICEF") for the manufacture of penicillin and other antibiotics. ${ }^{127}$ This resulted in the establishment of the Hindustan Antibiotic Limited in 1954 to manufacture drugs at a cheaper cost for the public. ${ }^{128}$ Next, the government appointed the Justice Rajagopala-Ayyangar Committee in $1957^{129}$ to recommend revisions to the patent law to suit local industrial needs. ${ }^{130}$ The object of the committee was to ensure that India developed a locally sustainable pharmaceutical market. ${ }^{131}$ The committee's 1959 recommendations formed the foundation for patent law in India. ${ }^{132}$

124. Id. at 65 .

125. Id. at 66 .

126. Id. The amendment vested the controller with the power to grant a patent unless there were "good reasons" to refuse. Id.

127. See Hindustan antibiotics Limited Health-Care and Agrovet Products, Profile (1999) at http://www.hindantibiotics.com/htdocs/profile.html (last visited Jan. 28, 2003).

128. Id.

129. Government of India, Patents EnQuiry Committee, Report on the ReVISION of THE PATENTS LAW (Sept. 1959) (by Shri Justice N. Rajagopala-Ayyangar) [hereinafter RAJAGOPALA-AYYANGAR REPORT]. The report of this committee is considered to be the backbone of the Indian Patent legislation enacted in 1970. Ragavan, supra note 110, at n.2.

130. Banjeri, supra note 102, at 63.

131. See V.R. Krishna Iyer, Human Health and Patent Law, FrontLine, Oct. 14-27, 2000, at 21, available at http://www.flonnet.com/f11721/17210790.htm (last visited Jan. 28, 2003).

132. V.R. Krishna Iyer, GATT, TRIPS and Patent Law, THE HINDU, Sept. 11, 2000, at 5. The wide admiration for the Rajagopala-Ayyangar report has been recorded in the words of Justice Krishna Iyer, a renowned Supreme Court Justice in India:

A well-debated, development-oriented and patriotically processed statute of 1970, with a progressive perspective and successful sequel, passed after a thorough study (based on the Justice Rajagopala Ayyangar Commission report) proved a tremendous national triumph for the consumer and the manufacturer alike. [It proved to be the] finest and most just parliamentary Id. achievement .... . 
The Rajagopala-Ayyangar Report embraced the patent system by observing that, " $[\mathrm{m}]$ anufacturers would not be prepared to develop and produce important machinery if others could get the results of their work with impunity." 133 This Report pointed out several shortcomings in the functioning of the Indian patent system ${ }^{134}$ and indicated that the lack of a clear directive in the patent legislation enabled multinational companies to use the legislative loopholes to their benefit. ${ }^{135}$ The Report pointed to a decision ${ }^{136}$ of the Bombay High Court ${ }^{137}$ where the issue was whether using a different process of production ${ }^{138}$ would amount to an infringement of the patent for the product. ${ }^{139}$ The Report pointed out that the ambiguity in the legislation provided for overly broad claims. ${ }^{140}$ This enabled patentees to cover several processes of production and thus limit innovation.

In recommending changes, the Ayyangar committee was bound by the provisions of the Indian Constitution. Article 21 of the Constitution

133. Iyer, supra note 131.

134. There were several instances where licenses to manufacture were denied although the patentees were not working the patents. Banjeri, supra note 102, at 64 .

135. For example, the Rajagopala-Ayyangar Report pointed to the case of Farwerke Hoechst v. Unichem Labs., 1969 A.I.R. 56 (Bom.) 255 (India).

136. Hoechst, 1969 A.I.R. 56 (Bom.) 255 (India).

137. High Courts in India are courts of appeal established by the Constitution of India. INDIA CONST. ch. IV, art. 124. Every state within the country has a high court. The high courts are the highest court of appeal within the state. The Supreme Court of India, the highest court in the country, is the next level of appeal from the high courts. Indian Courts, Indian Judiciary, Ministry of Communications and Information, at http://indiancourts.nic.in/Indian_jud.htm (last visited Mar. 17, 2003).

138. Tolbutamide was the end product in both processes. The defendant manufacturer used the method of desulfurization with hydrogen peroxide. The plaintiff manufactured sulphonylureas of the general formula $\mathrm{R}-\mathrm{SO}_{2}-\mathrm{NH}-\mathrm{CO}-\mathrm{NH}-\mathrm{RI}$ where the thioureas of the formula $\mathrm{R}-\mathrm{SO}_{2}-\mathrm{NH}-\mathrm{CS}-\mathrm{NH}-\mathrm{R} \mathrm{l}$ were treated with agents eliminating the sulphur to produce tolbutamide. Hoechst, 1969 A.I.R. 56 (Bom.) 255 at 258, 263 (India).

139. Id. at 258,259 . In this case the Haffkine Institute of India produced tolbutamide from locally available raw materials and patented the process. Id. at 258 . Hoechst filed a suit claiming that the tolbutamide was mentioned in their 1956 patent application for producing benzonesuplhonyl urea. Id. The Bombay High Court noted that tolbutamide was only a byproduct in the Hoechst application and that the Haffkine process was not mentioned in the patent application. Id at 261 . The process of production differed in both cases although the end product remained the same. Id. at 264.

140. RAJAGOPALA-AYYANGAR REPORT, supra note 129 , at 60 . The claim language of Hoechst was wide and covered all processes of production permitted by the ambiguity in the legislation. Hoechst, 1969 A.I.R. 56 (Bom.) at 260 (India). Claim 22 of the application detailed that "[t]he compounds of the formula shown in Fig. 6 of the drawings, whenever obtained according to claims 1-15." Id. at 263. Figure 6 contained the formula of tolbutamide. Id. However, Claim one "cover[ed] compounds obtained by the chemical reaction specified therein, either directly . . . or indirectly. ..." Id. at 264. The court found in favor of Hoechst because the patent legislation was ambiguous enough to accommodate broad claims covering much beyond the scope of the inventions. Id. at 264-65. 
guarantees the right to life, ${ }^{141}$ which includes the right to good health. ${ }^{142}$ The Preamble of the Constitution requires policies to balance "social and economic" rights. ${ }^{143}$ Hence, public health concerns need to be weighed with business interests in amending the patent legislation. The RajagopalaAyyangar Report argued that a patent policy vesting an unrestrained monopoly would deny vast sections of India's population access to medicine. ${ }^{144}$ Hence, the report concluded that vesting unfettered monopoly rights violated the right to good health guaranteed under the Indian Constitution. ${ }^{145}$ The report proposed a compulsory licensing system and a process for patenting drugs as means to develop a local pharmaceutical industry in India. ${ }^{146}$

Based on the Rajagopala-Ayyangar Report, a bill was introduced in $1965 .^{147}$ Although the Lok Sabha passed this bill, it lapsed in the Upper House. $^{148}$ A revised bill ${ }^{149}$ was re-introduced in 1967 and passed in 1970 for which the draft rules were passed in 1971. The act and the rules came into force in 1972 . $^{150}$

\section{b. Solutions in Price Control}

The enactment of the patent legislation paved a path for local manufacturing of drugs. However, the drug prices had to be affordable to the poor. Hence, the Drug Price Control Order was passed in $1970^{151}$ to

141. INDIA CONST. art. 21.

142. Iyer, supra note 131 , at 21 .

143. INDIA CONST. pmbl.

144. Banjeri, supra note 102 , at 65 .

145. V.R. Krishna Iyer, Patent Law-Patently Unfair?, THE HINDU, Mar. 3, 2002, at Opinion Section.

146. Banjeri, supra note 102 , at 69 .

147. See Rajiv Jain \& Rakhee Biswas, Law of Patents: Procedure \& Practice $\$ 1.1$ (2d ed. 1999).

148. Ragavan, supra note 110. There are two houses of Parliament in India, the lower house or the Lok Sabha [hereinafter Lower House] and the Rajya Sabha [hereinafter Upper House]. Indian Parliament, Introduction, at http://alfa.nic.in/intro/introparl.htm (last visited Mar. 14, 2003). The Lower House is comparable to the House of Commons and the Upper House to the House of Lords in England.

149. JAIN \& BISWAS, supra note $147, \S 1.1$. A joint committee of Parliament was formed to study the bill. Id. The suggestions of the Joint Parliamentary Commissioni were incorporated and the bill was introduced again as the Patents (Amendment) Bill, 1965. Id. In 1966, the revised bill was tabled again in the Lower House but it lapsed due to the dissolution of the Lower House. Id.

150. Patents Act of 1970, 27 INDIA A.I.R. MANUAL 450 (2d ed. 1979).

151. The Drug Policy was established in the year 1978. Banerji, supra note 102, at 84 . 
enable the government to control drug prices and provide maximum accessibility of medication to the poor. ${ }^{152}$

A revision introduced to the Drug Price Control Order in 1984 compartmentalized drugs into three categories and exercised price control over 347 bulk drugs and 4000 formulations. ${ }^{153}$ The Drug Policy of 1986 established a new price control regime. ${ }^{154}$ This revised policy reduced the number of categories for price control to two. ${ }^{155}$ The number of drugs under price control was reduced to $143 .^{156}$ This policy encouraged competition for the first time while ensuring "abundant availability of essential, life-saving, and prophylactic medicines of good quality at reasonable prices." 157 Additionally, the National Pharmaceutical Pricing Authority was created to review pharmaceuticals under price control and monitor the prices of decontrolled pharmaceuticals. ${ }^{158}$ This authority revised the Drug Policy Control Order in 1987..$^{159}$

A new price control evolved with the Modifications in Drug Policy in 1994. ${ }^{160}$ A uniform Maximum Allowable Post-Manufacturing Expense for price control was established for both categories. ${ }^{161}$ A minimum turnover of $\$ 1,300,000$ per year was required to enforce price control. ${ }^{162}$ Pharmaceuticals having sufficient market competition ${ }^{163}$ are exempt from price controls. ${ }^{164}$ This policy reduced the number of price-controlled

152. Id. After the Drug Price Control Order was passed, the government of India placed most drugs under price control. Id.

153. The categories were meant to separate drugs most essential for the national health care programs from the other drugs. Id. The degree of price control exercised varied with the category of the drug. Id.

154. Suresh Koshy, The Effect of TRIPs on Indian Patent Law: A Pharmaceutical Industry Perspective, 1 B.U. J. SCI. \& TECH. L. I 36, at 4 (1995) (listing 21 category I drugs and 122 category II drugs).

155. Id. ๆ 26. Category I consists of drugs for the National Health Program and category II encompasses drugs for health needs. Id. The "Maximum Allowable Post-Manufacturing Expense" for price control in category I is $75 \%$ and category II is $100 \%$. Id. Thus there was a separate price-markup ceiling for each category. Id. The post-manufacturing expenses include advertising and distribution costs. Id.

156. Id.

157. Id. ๆ 25.

158. Id. $\ 27$.

159. Id. $\uparrow 26$.

160. Modifications to Drug Policy, Centre for Monitoring Indian Economy (April 1996), at http://indianconsulate-sf.org/iebo/drug.htm (last visited Mar. 17, 2003).

161. Koshy, supra note 154 ๆ 26.

162. Koshy, supra note 154 \27.

163. Id. ๆ 27. Sufficient market competition is indicated by the presence of at least five active ingredient producers and ten formulators and no more than forty percent of the market share. Id.

164. Id. 
pharmaceuticals to a mere seventy-three. ${ }^{165}$ The policy enhanced incentives to research and development by exempting active ingredient manufacturers from price control for ten years, provided inventive processes were developed through research and development. ${ }^{166}$

The various drug price control orders ensured availability of drugs at affordable costs. Although pharmaceutical prices were controlled, the Indian government, to its credit, attempted to phase out these controls with the growth of the indigenous pharmaceutical industry. ${ }^{167}$ Unfortunately, because the same realities of poverty that forced India to adopt a process patent legislation remain unaltered, the drug price control could not be totally abolished. ${ }^{168}$ In $1993,37 \%$ of the Indian population lived below the poverty line. ${ }^{169}$ The ninth five-year plan estimated that 320 million people lived below poverty line. ${ }^{170}$ As late as 2001 , the Indian Prime Minster detailed elimination of poverty as a primary objective in the opening address for the tenth five-year plan. ${ }^{171}$

\section{Poverty Issues in Brazil}

Like India, Brazil also embraced a weak intellectual property system in order to provide for the poor. The Brazilian government abolished patent protection for pharmaceutical products in 1969. ${ }^{172}$ The government reasoned that it would "create a stronger domestic pharmaceutical industry in the face of the dominant foreign multinational competitors." 1971, Brazil [totally] abrogated patent protection for pharmaceutical manufacturing processes" to provide medicines for the poor. ${ }^{174}$ The state-

165. Id.

166. Id.

167. Id. $9725,27$.

168. Although the per capita income has increased, poverty continues to be a problem. See id. ๆ9 36-37.

169. Reducing Poverty in Indian: Options for More Effective Public Services, World Bank Group (June 29, 1998), at http://poverty.worldbank.org/library/new/8679 (last visited Mar. 17, 2003 ) (indicating $37 \%$ in rural areas and $31 \%$ in urban areas).

170. Government of India, Planning Comm'N Off. Doc., Ninth Five Yr. Plan, (19972002) (Vol. I \& II) (Jan. 2002), available at http://www.planningcommission.nic.in/fiveyr/ default.html.

171. Government of India, Planning Comm'n Off. Doc., Tenth Five Yr. Plan, (2002-2007) (Vol I \& II) (Jan. 2002), available at http://www.planningcommission. nic.in/fiveyr/default.html.

172. See Christopher S. Mayer, The Brazilian Pharmaceutical Industry Goes Walking from Ipanema to Prosperity: Will the New Intellectual Property Law Spur Domestic Investment?, 12 TEMP. INT'L \& COMP. L.J. 377, 379 (1998).

173. Id.

174. Id. 
owned Central de Medicamentos was created and a master plan was drafted for the implementation of the 1971 policy, under the direct supervision of the President. ${ }^{175}$ The plan revived state-owned laboratories and vested preferential treatment in local companies to promote domestic manufacture of pharmaceuticals without "threaten[ing] ... growth of private and domestic firms." 176 . This enabled the development of a generic drug industry in Brazil, which accounted for approximately $15 \%$ of the Brazilian market. ${ }^{177}$ Not until 1996 did Brazil provide for patent protection under a new Industrial Property Law. ${ }^{178}$ The patent term was extended to twenty years from the date of patent application in the country of origin. ${ }^{179}$ Specialized courts were also established to hear patent disputes. ${ }^{180}$

The 550,000 known HIV cases in Brazil, a country of 170 million people, threatened its public health safety. ${ }^{181}$ Thus, Brazil had to provide its low-income population with affordable, generic equivalents to costly HIV medicine. A local working requirement was also introduced empowering the Brazilian government to grant a compulsory license for drugs not produced within Brazil. ${ }^{182}$ Local pharmaceutical companies manufactured generic versions of eight of the twelve drugs in the AIDS "cocktail" at $70 \%$ below market price. ${ }^{183}$ The compulsory license scheme of the government enabled free treatment for 100,000 low-income patients each year. ${ }^{184}$ Thereafter, Brazil demonstrated a significant improvement in public health. ${ }^{185}$ The government claims to have saved $\$ 420$ million in AIDS drugs. ${ }^{186}$ Because "approximately 540,000 Brazilians [are still] infected with HIV/AIDS," Brazil continues to aggressively pursue the compulsory license scheme in its patent policy. ${ }^{187}$

175. Id.

176. $I d$.

177. Id. at 388 .

178. Id.

179. Id.

180. Id. at 389 .

181. Jessica Galeria, Patients Ignored: Brazil Puts AIDS Case Before Drug Profits, AMERICAS.ORG, at http://www.Americas.org/News/Features/200104_Brazil_AIDS_Drugs/200 10401_index.asp (last visited Mar. 14, 2003).

182. See National Production of Antiretroviral Drugs, National AIDS DRUGS POLICY, June 2001, available at http://www.aids.gov.br/final/biblioteca/drug/drug5.htm (last visited Jan. 23, 2003).

183. Id.

184. Id.

185. Galeria, supra note 181; see also Naomi A. Bass, Implications of the TRIPS Agreement for Developing Countries: Pharmaceutical Patent Laws in Brazil and South Africa in the 21st Century, 34 GEO. WASH. INT'L L. REV. 191, 209 (2002).

186. Bass, supra note 185, at 209.

187. Id. 
Like Brazil and India, most developing countries house high populations with larger shares of diseases. Low literacy rates and limited education contribute to poverty and increase the need for low-priced necessities. The great number of indigent citizens creates an incredible demand on the governments to provide medical supplies at affordable prices. ${ }^{188}$ Thus, the generic drug industry developed using patent policy as a mandate to provide affordable medication for the poor communities.

\section{THE STORY OF DEVELOPING NATIONS EMBRACING TRIPS}

The developed nations have uniformly encountered problems with specific features of the patent regimes of developing nations. The discussion below specifies the features of the Indian Patent Act of 1970 and highlights those aspects that directly contravene TRIPS. It traces how developing countries tackled local issues using patent policies. Thereafter, the discussion focuses on how the Indian government was pressured into "voluntarily" amending its patent legislation. Under international pressure, governments had to totally ignore the effects and the reactions of the people to the amendment.

\section{A. Patenting in India}

The analysis of the Indian patent legislation vis-à-vis the TRIPS provisions highlights how developing nations structure patent legislation to alleviate poverty and health care issues. It shows that developed nations cannot hope to move developing nations successfully towards a trade regime unless solutions are devised for problems addressed by the preTRIPS legislations in developed countries.

\section{Patentable Inventions in India}

Under the Patents Act of 1970 ("the Act") any "new" and "useful" invention, ${ }^{189}$ qualifies for a patent, provided the claims and the specifications can be read in that light. ${ }^{190}$ The terms "new" and "useful" were not statutorily defined. Hence, the Supreme Court of India enunciated the test of the inventive step to define "new" and "useful" as the novelty

188. See Koshy, supra note 154, ๆ 36 .

189. Patents Act of 1970, 27 INDIA A.I.R. MANUal 450, § 2(j) (2d ed. 1979).

190. See Raj Parkash v. Mangat Ram Choudhary, 1978 A.I.R. 65 (Del.) 1, 7 (India) 
and utility requirement. ${ }^{191}$ The issue of whether an invention is "new" and "useful" is a mixed question of law and fact.

The Indian patent legislation neither defines non-obviousness, nor makes non-obviousness a test for patentability. The test of non-obviousness can be used only for patent opposition. In Press Metal Corporation, Ltd., v. Noshir Shorabji, ${ }^{192}$ the Bombay High Court held that to be patentable an invention has to be non-obvious. ${ }^{193}$ Obviousness is judged by the standard of a man skilled in the specific art. ${ }^{194}$ Thus the court intertwined non-obviousness within the novelty and utility requirement. ${ }^{195}$

Section 3 of the Act excludes certain inventions from patentability. ${ }^{196}$ "[I]nvention[s], the primary or intended use of which would be contrary to law or morality or injurious to public health," ${ }^{197}$ are excluded from patentability to facilitate compulsory license. ${ }^{198}$ Biotech patents have been excluded on the premise that the definition of "manufacture" does not include living organisms and that the definition of "substances" excludes

191. Bishwanath Prasad Radhey Shyam v. Hindustan Metal Industries, A.I.R. 1982 S.C. 1444 (India).

192. 1983 A.I.R. (Bom.) 144 (India).

193. Id. at 144.

194. Id. at 144-45.

195. Id.

196. Section 3 of Patents Act, 1970 states:

The following are not inventions within the meaning of this Act: a) an invention which is frivolous or which claims anything obvious contrary to well established natural laws; b) an invention the primary or intended use of which would be contrary to law or morality or injurious to public health; c) the mere discovery of a scientific principle or the formulation of an abstract theory; d) the mere discovery of any new property or new use for a known substance or of the mere use of a known process, machine or apparatus unless such known process results in a new product or employs at least one new reactant; e) a substance obtained by a mere admixture resulting only in the aggregation of the properties of the components thereof or a process for producing such substance; f) the mere arrangement or re-arrangement or duplication of known devices each functioning independently of one another in a known way; g) a method or process of testing applicable during the process of manufacture for rendering the machine, apparatus or other equipment more efficient or for the improvement or restoration of the existing machine, apparatus or other equipment or for the improvement or control of manufacture; h) a method of agriculture or horticulture; i) any process for the medicinal, surgical, curative, prophylactic or another treatment of human beings or any process for a similar treatment of animals or plants to render them free of disease or to increase their economic value or that of their products.

Patents Act of 1970, 27 India A.I.R. Manual 450, § 3 ( 2 d ed. 1979).

197. Id. § 3(b).

198. See id. This clause is similar to the exception under article 27 in TRIPS. See TRIPS Agreement, supra note 8, art. 27(2). 
living organisms. 199 The "law or morality" phrase in section 3 may also raise issues concerning the patentability of biotech patents. ${ }^{200}$ Exclusion of a "mere discovery of a scientific principle or the formulation of an abstract theory" denies protection to software-related material. ${ }^{201}$ Clause (h) of section 3 excludes "a method of agriculture or horticulture"202 and does not provide for plant varieties protection. ${ }^{203}$ Notably, protection of plant varieties by some form of intellectual property is mandatory under TRIPS. $^{204}$

\section{Process Patents in India}

A patent may be granted for a product or a process. ${ }^{205}$ A product patent protects the end product. Process patents limit protection to the process of production or the method of making. The Patents Act merely awards process patent protection for inventions relating to food, drugs, medicine, and chemical processes. ${ }^{206}$ Since the actual product is not protected, the same product may be manufactured by another process. Therefore, several processes of producing the same product can be subjects of different process patents. This provision contravenes articles 27 and 28 of TRIPS. Article 27 stipulates that "patents shall be available for any inventions, whether products or processes, in all fields of technology" in all member

199. Dimminaco A.G. v. Controller of Patents Designs, 2001 A.I.R. 1 (Cal.), 7-8 (India).

200. Patents Act of 1970, 27 India A.I.R. MANUal 450, $\S 3$ (b) (2d ed. 1979). Although there are no cases decided so far in India on this point, there are several cases from the European Patent Convention, which has objectives similar to TRIPS. See, e.g., Howard Florey/Relaxin, (opposition by Fraktion der Grünen im Europäischen Parlament; Lannoye), 1995 E.P.O.R. 541 (Germany); Plant Genetic Systems/Glutamine Synthetase Inhibitors (Opposition by Greenpeace), 1995 E.P.O.R. 357 (Germany).

201. Patents Act of 1970, 27 India A.I.R. Manual 450, § 3(c) ( 2 d ed. 1979).

202. Id. $\S 3(\mathrm{~h})$.

203. New plant variety protection legislation was introduced in 1999 to coincide with TRIPS. Plant Variety Protection and Farmers Rights Bill (1999) (enacted 2002).

204. TRIPS Agreement, supra note 8, art. 27(3)(b) ("Members shall provide for the protection of plant varieties either by patents or by an effective sui generis system or by any combination thereof.").

205. Patents Act of 1970, 27 India A.I.R. MANUAL 450, § 3(d) (2d ed. 1979).

206. Section 5 of the Patents Act provides that in the case of inventions a) claiming substances intended for use, or capable of being used, as food or as medicine or drug, or b) relating to substances prepared or produced by chemical processes (including alloys, optical glass, semi conductors and inter metallic compounds), no patent shall be granted in respect of claims for the substance themselves, but claims for the methods or processes of manufacture shall be patentable.

Id. $\S 5$. 
states. ${ }^{207}$ Article 28 prohibits third parties from using the product where the subject matter of the patent is the process. ${ }^{208}$

\section{Compulsory Licenses and Working of Patents in India}

The Ayyangar committee's recommendations to balance economic and social justice resulted in provisions on compulsory licenses and local manufacturing of patents. Compulsory licenses enable the government to intervene if the patents are not worked for the benefit of the people. The local manufacturing requirement of the patented products ensures "that patented inventions are worked [locally] on a commercial scale ... to the fullest extent that is reasonably practicable." ${ }^{209}$ Any interested third party can seek a compulsory license three years after a patent is granted. ${ }^{210}$ Compulsory licenses are granted under section 84 on the grounds that either the patent has not been worked to satisfy the reasonable requirement of the public, or that the patented invention is not reasonably priced. ${ }^{211}$ The controller of patents can compulsorily license the patent, taking into account several factors including the nature of the invention and the applicant's ability to work the invention to the advantage of the public. ${ }^{212}$

Alternatively, under section 86 , the central government has the right to request that the controller endorse a patent with the "license of right." 213 Licenses of right are granted on the same grounds as compulsory licenses. $^{214}$ If the controller is satisfied with the arguments of the central government, the controller can issue an order endorsing the patent with a "license of right" under section 86(2). ${ }^{215}$ Section 87 deems that a license of right is endorsed three years after the date of sealing the patent for inventions in food, medicine, drug and chemical processes. ${ }^{216} \mathrm{~A}$ patent subjected to either a compulsory license or a license of right is open under section 88 for any person interested in working the patent to acquire a manufacturing license notwithstanding the patentee's approval. ${ }^{217}$ The concept of licenses of right is alien to TRIPS. TRIPS does, however,

207. TRIPS Agreement, supra note 8 , art. 27(1).

208. Id. art. 28(1)(b).

209. Patents Act of 1970, 27 India A.I.R. MANUal 450, § 94 ( 2 d ed. 1979).

210. Id. $\S 84(1)$.

211. Id.

212. Id. § 85(i)-(ii).

213. Id. $\S 86(1)$.

214. Id.

215. Id. $\S 86(2)$.

216. Id. $\S 87(1)$. These are inventions entitled to process patents under section 5. Id. $\S 5$.

217. Id. $\S 88$. 
provide for compulsory licenses under article 31 , subject to certain terms and conditions. ${ }^{218}$

Satisfying the reasonableness requirement of the public is a precondition to avoiding compulsory licensing of the patent. Section 90(c) of the Patents Act deems that the reasonableness requirement of the public is not satisfied unless the invention has worked within India. ${ }^{219}$ The "reasonable requirement of the public" condition is also violated under section 90 if any "establishment or development of commercial activities in India is prejudiced" because the patentee refuses to license the patent. ${ }^{220}$ Article 27(1) of TRIPS stipulates that patent rights shall be enjoyed "without discrimination as to the place of invention, the field of technology and whether the products are imported or locally produced."221 TRIPS does not distinguish between an importer and a local producer; it vests the same rights on both. ${ }^{222}$

\section{Term of Patents in India}

Section 53(1) of the Act vests process patents in food, drugs, and medicines for five years from the date of sealing or seven years from the date of filing a complete specification, whichever is shorter. ${ }^{223}$ However, a license of right is deemed to vest on inventions relating to food, drugs, and medicines after three years of patent protection. ${ }^{224}$ Therefore, exclusive protection is effectively provided for only three years. ${ }^{225}$ Patent protection for other inventions is available for a period of fourteen years, ${ }^{226}$ unlike the twenty-year protection prescribed in TRIPS. ${ }^{227}$

\section{Burden of Proof (in India)}

The Indian Patent Act does not vest the burden of proof of infringement on either party. However, the Nagpur High court held in the 1953 case Bombay Agarwal v. Ramchand Diwan Chand" ${ }^{228}$ that the "onus of proving

218. TRIPS Agreement, supra note 8, art. 31.

219. Patents Act of 1970, 27 India A.I.R. MANUAL 450, $\S 90$ (c) (2d ed. 1979).

220. Id. $\S 90$ (a)(iv).

221. TRIPS Agreement, supra note 8 , art. 27(1).

222. Id.

223. Patents Act of 1970, 27 INDIA A.I.R. MANUAL 450, § 53(1)(a) (2d ed. 1979).

224. Id. $\S \S 86(1), 87(1)(\mathrm{a})(\mathrm{i})$.

225. Id.

226. Id. $\S 53(1)(\mathrm{b})$.

227. TRIPS Agreement, supra note 8, art. 33.

228. 1953 A.I.R. 40 (Nag.) 154 (India). 
the infringement lies upon the plaintiff, who has not only to prove the patent in his favour, but also to prove that the patent is being infringed by resorting to a process patented by the plaintiff."229 This contravenes article 34 of TRIPS which vests the burden of proof on the defendant in all civil proceedings relating to infringement of process patents. ${ }^{230}$ Article 34 applies if the patented process is used to obtain a new product or if the patent owner is unable to determine the process used in an identical product. $^{231}$

\section{B. India TRIPS at Marrakech}

India was amidst political turmoil when it was obtaining WTO membership. Congress (I) ${ }^{232}$ was in power from 1986 to $1989,{ }^{233}$ and it refused to negotiate over patent reform when the Uruguay Round negotiations were concluded. ${ }^{234}$ Congress (I) lost its majority in the parliament in $1989 .{ }^{235}$ In 1996 , Congress (I) became the ruling minority government when India became a signatory to the TRIPS agreement. ${ }^{236}$ India had no obligation to comply with TRIPS for one year from the date of the Agreement (April 1994), except for article 70, sub-clauses (8) and (9) which mandated the immediate establishment of an interim mechanism to provide exclusive marketing rights for agricultural, chemical and pharmaceutical products. ${ }^{237}$ India could not afford to violate TRIPS and

229. Id. at 157.

230. TRIPS Agreement, supra note 8, art. 34(1).

231. Id.

232. George K. Foster, Comment, Opposing Forces in a Revolution in International Patent Protection: The U.S. and India in the Uruguay Round and its Aftermath, 3 UCLA J. INT'L L. \& FOREIGN AFF. 283, 319 (1998). Congress (I) is one of the major political parties in India that was in power before the current Bharatiya Janata Party ("BJP"). The original Congress party was split into Congress (I) and Congress (J). Congress (I) signified that part of the party that was led by Mrs. Indira Gandhi, the former Prime Minister of India. Congress (J) stands for the Janata Congress-another faction of the original Congress party. Id.

233. Id.

234. Id. at 320 .

235. Id. at 319 .

236. Id. In the elections of May 1996, the BJP won 162 seats while the Congress (I) won 140 seats. Id. That left India with a coalition government consisting of the United Front a coalition of regional parties, and Congress (I). Id. at 319-20.

237. TRIPS Agreement, supra note 8, art. 70(8)-(9). This interim mechanism, also known as the "mail box provision," was meant to facilitate filing patent applications in chemicals, food, and drugs until the product patent regime was established. Shishir Mehta \& Rajesh Chavda, The Mailbox Dispute and Implications on Indian Patent Regime, THE STUDENT ADVOCATE If 5 , at 40 (1998). 
face trade sanctions impacting Indian exports. ${ }^{238}$ However, Congress (I) sensed that local economic conditions would impede amendments to the Patents Act of $1970 .^{239}$ Congress (I) also understood that patent amendments would directly affect the party's popularity among the people. ${ }^{240}$ Hence, Congress (I) was forced to take an ambiguous position in fear of Special 301 on one side and local politics on the other. ${ }^{241}$

At the end of the parliamentary session on December 31, 1994, the President of India promulgated the Patents (Amendment) Ordinance ${ }^{242}$ and amended the Patents Act, $1970 .{ }^{243}$ The ordinance became effective January 1,1995 , and India notified the council for TRIPS under article $63(2) .{ }^{244} \mathrm{~A}$ press note was issued stating that the Indian government had appointed an expert committee to examine issues arising from the grant of exclusive marketing rights. ${ }^{245}$ However, the ordinance was not approved in both houses within six weeks of the re-assembly of the Parliament and, as a result, it lapsed on March 26, $1995 .{ }^{246}$

By this time, the Bharatiya Janata Party ("BJP") was in power. ${ }^{247}$ Like Congress, the BJP also sensed that amending the patent legislation would negatively impact its new-found popularity. ${ }^{248}$ Influenced by international pressure, the BJP government passed the Patents (Amendment) Bill 1995. ${ }^{249}$ This bill intended to give permanent legislative effect to the ordinance. ${ }^{250}$ The Lok Sabha passed the bill in March 1995. ${ }^{251}$ Unfortunately, the bill failed in the Rajya Sabha and was referred to the select parliamentary committee $^{252}$ for examination. The report of the select committee was not

238. Foster, supra note 232, at 317 (noting that the United States was "extending preferential tariff treatment under the GATT Generalized System of Preferences (GSP) ... [t]he U.S. revoked duty-free treatment under the GSP for India's exports of pharmaceuticals, citing India's poor protection of U.S. patented drugs . . . result[ing] in a levy of $\$ 60$ million[,]" thus reducing Indian exports) (internal citation omitted).

239. Id. at 321 .

240. See id.

241. Id. at 317,321 .

242. Mehta \& Chavda, supra note 237 , 7 . In India, ordinances have the force of law provided both houses approve the ordinance within six weeks of the beginning of a new session of the parliament. Id.

243. Banerji, supra note 102 , at 61 .

244. Mehta \& Chavda, supra note 237 , $1917-8$.

245. Id.

246. Id. 77.

247. Foster, supra note 232, at 319-20.

248. Id. at 321 .

249. Mehta \& Chavda, supra note 237, 99.

250. Id.

251. Id.

252. Id. In India, a bill has to be approved by a simple majority in both Houses of the Parliament before it is passed. The bill is then assented to by the President to become an act. 
tabled before the dissolution of the Lok Sabha on May 10, 1996; hence the Patents (Amendment) Bill lapsed with the dissolution of the tenth Lok Sabha. ${ }^{253}$ The Indian government instituted an administrative order to accept patent applications in the interim. ${ }^{254}$

Meanwhile, the United States, tired of waiting for India to comply with TRIPS, sought consultation through the WTO. ${ }^{255}$ The United States requested that the Dispute Settlement Body of the WTO examine whether India defaulted on its TRIPS obligation. ${ }^{256}$ India argued that since the applications for chemical and biological patents were being filed, "effective means," as required by TRIPS, had been effectuated. ${ }^{257}$ Furthermore, India argued that developing countries were entitled to delay the process under article 65(2) for four years. ${ }^{258}$ The United States countered that the mere fact that India issued an ordinance indicates the need for a formal legislation. ${ }^{259}$ The panel ruled that India was in default of its obligations and refused to consider the administrative notifications as a mechanism in compliance with the requirements under TRIPS. ${ }^{260}$ The panel's ruling mandated that India immediately implement a transitional system as required under $70(9) .{ }^{261}$ The appellate body upheld the panel decision. ${ }^{262}$

The bill lapses if the Lok Sabha does not approve it. If a bill is approved by the Lok Sabha, but not by the Rajya Sabha, a parliamentary committee is appointed to deliberate over it. The committee consults experts, academics, and other people concerned in that particular area of law. The committee's report is passed to the Parliament and to the concerned department. The government has the option of agreeing or disagreeing with the changes suggested. It is then sent to the Cabinet for approval, at which stage the bill is again placed before the Lok Sabha, and after approval, to the Rajya Sabha. Indian Parliament, Committees, at http://alfa.nic.in/rs/ book2/general.htm (last visited Mar. 14, 2003).

253. Mehta \& Chavda, supra note $237,99$.

254. Id. ๆ 14. Later, the Indian government would quote that this order was an "effective legal mechanism" fulfilling the requirements of TRIPS. Id.

255. The U.S. asked for a consultation on July 2, 1996, under article 4 of The Understanding read with Article 64 of TRIPS. The consultation failed on July 27, 1996. Id. Tी $5,10$.

256. Id. ๆ 11. The U.S. requested a panel to take up the dispute on November 7, 1996. Id. A panel was constituted under the procedures of the WTO on November 20, 1996. Id.

257. Id. ๆ14.

258. Id. \31.

259. Id. ๆ 34.

260. WTO Dispute Panel, India-Patent Protection for Pharmaceutical and Agricultural Chemical Products, WT/DS50/R at 81 (Sept. 5, 1997) [hereinafter Panel Report], available at http://www.wto.org/english/tratop_e/dispu_e/distabase_wto_membersl_e.htm.

261. Id.

262. WTO Appellate Body Report, India-Patent Protection for Pharmaceutical and Agricultural Chemical Products, WT/DS50/AB/R at 97 (Dec. 19, 1997) [hereinafter Appellate Report], available at http://www.wto.org/english/tratop_e/dispu_e/distabase_wto_ members1_e.htm. On appeal, India raised the issue of clarification of the interpretation of the term "means" in article 70(8) of TRIPS. Mehta \& Chavda, supra note $237,1760,64$. India 
The Dispute Settlement Body of the WTO formally adopted the findings in January $1998 .{ }^{263}$ This decision forced India to amend the patent legislation to avoid trade sanctions. ${ }^{264}$ The BJP and Congress (I) (the ruling and the opposition parties, respectively) worked together to put the delayed legislation in place. ${ }^{265}$ The Patents Amendment Act was thus passed in December $1999 .{ }^{266}$

This first patent amendment introduced Chapter IV-A, which established the interim mechanism for granting exclusive marketing rights as required by the WTO. ${ }^{267}$ A provision was introduced that would allow for the grant of exclusive marketing rights, provided the controller is satisfied that the claimed substance is patentable. ${ }^{268}$ The exclusive marketing right vests five years after the date of approval by the controller, or the determination of patentability, whichever is earlier. ${ }^{269}$ Prior publication or use of the claimed invention by a third party will not constitute infringement ${ }^{270}$ before the application is filed either in India or in a signatory country of the Patent Cooperation Treaty. ${ }^{271}$ The provisions relating to compulsory licensing apply in relation to the exclusive marketing right. ${ }^{272}$ The central government also retains the right under section $24 \mathrm{D}$ to revoke the exclusive

also questioned whether article 70(8) mandated providing exclusive marketing rights from the date of entry into force of TRIPS. Id $\$$. 64 . The appellate body held that India was obliged to provide a legal mechanism for an interim mailbox arrangement. Id. \65. This mechanism needs to be couched on a sound legal basis to preserve the novelty of inventions and priority of applications as of the relevant filing dates. Id. "Administrative instructions" cannot constitute a sound legal basis. Id. The appellate body added that Article 70(9) mandates that upon becoming a member, India should have an effective legal mechanism, "to provide for the grant of exclusive marketing rights." Id. \66.

263. WTO Appellate Body Report Action by the Dispute Settlement Body, India-Patent Protection for Pharmaceutical and Agricultural Chemical Products, WT/DS50/9 (Jan. 27, 1998) [hereinafter DSB Action] available at http://www.wto.org/english/tratop_e/ dispu_e/distabase_wto_membersl_e.htm.

264. Mehta \& Chavda, supra note 237, श1 73-74.

265. See id.

266. Patents Amendment Act (1999) (India).

267. Id. Section $24 \mathrm{~A}(1)$ was introduced in the Patent legislation mandating the controller to refer applications seeking an exclusive marketing right to an examiner and then determine patentability of the invention. Chapter VI-A, Patents Amendment Act 1999. Id. §24A(1).

268. Id. $\S 24 \mathrm{~A}(2)$.

269. Id. $\S 24 \mathrm{~B}(1)(\mathrm{b})$. A report on the determination of patentability has to be submitted within ninety days under rules $33(\mathrm{C})$ and 33(D) of the draft rules. Ministry of Industry, Patent (Amendment) Rules $\S 33$ (C)-(D) (India 1999).

270. Patents Amendment Act $\S 24 B(2)$.

271. Patent Cooperation Treaty, June 19, 1970, 28 U.S.T. 7645.

272. Patents Amendment Act $\S 24(C)$. 
marketing right in public interest. ${ }^{273}$ This mechanism is effective in India until the product patent regime is established in December $2004 .{ }^{274}$

Under article 70(9) of TRIPS, India was required to fulfill the other obligations under article 65(2) by January $1,2000 .{ }^{275}$ Therefore, the Patents Amendment Bill 1999 was introduced in the Upper House on December 20, $1999 .^{276}$ The object of the bill was to make patent law in India TRIPScompliant. ${ }^{277}$ This bill amended the patent term to twenty years ${ }^{278}$ and amended the definition of "invention" in section $2(j) .{ }^{279}$ The new definition required inventions "capable of industrial application" to have an "inventive step." 280 The test for "inventive step" was novelty. ${ }^{281}$ Section 3 of the Patent Act of $1970^{282}$ was amended, but reiterated that biological processes and computer programs are not patentable. ${ }^{283}$ Plants and animals other than microorganisms, a novel business method or mathematical algorithm, among other things, also did not qualify as "inventions" under section $3^{284}$-although this could be justified under Article 27 of TRIPS. ${ }^{285}$

The second bill placed the burden of proof on the defendant in a patent infringement case. ${ }^{286}$ The bill deleted the local manufacturing requirement, but retained "non-working the patented article in India" as a ground for compulsory licensing from the previous section $84 .^{287}$ Section 90 (c), detailing inadequate working of the patent on a commercial scale as a ground for compulsory licensing, was not deleted. This implies that manufacturing abroad would continue as a ground for compulsory licensing.

273. Id. $\S 24(\mathrm{D})$.

274. Mehta \& Chavda, supra note $237, \uparrow 75$.

275. TRIPS Agreement, supra note 8, art. 70(9).

276. Patents (Second) Amendment Bill (1999) (India).

277. Statement of Objects and Reasons, Patents (Second) Amendment Bill (1999) (India) (introduced in the Rajya Sabha on Dec. 20, 1999) (Document No. XLIX 1999).

278. Id. cls. 21, 24 (codified as amended at Patents Act $1970 \S 53(1)(b)$ ).

279. Patents (Second) Amendment Bill § 3(f).

280. Id. $\S 3(\mathrm{j})$. “"Invention' means a new product or process involving an inventive step and capable of industrial application; 'inventive step' means a feature that makes the invention not obvious to a person skilled in the art." Id. §3(ja).

281. See id.

282. Patents Act of 1970, 27 India A.I.R. Manual 450, $\S 3$ (2d. ed. 1979) (listing items excluded from patentability).

283. Patents Amendment Bill $\S 4(e)$.

284. Id.

285. TRIPS Agreement, supra note 8, art. 27.

286. Patents Amendment Bill $\S 50$. This provision refers to process patents because India had five more years at the time of the bill to fall within the product patent regime. Id.

287. Id. § 39(b). 
As a balancing mechanism, the Department of Health ${ }^{288}$ issued a notification recognizing foreign manufacturers of drugs. ${ }^{289}$ This notification required foreign manufacturers to obtain a Certificate of Registration for each of the premises where drugs were manufactured for import into India. ${ }^{290}$ The applicant is liable under the notification for the payment of fees, charges, and prescribed expenditure. ${ }^{291}$ The concerned authority, or a person duly authorized, can inspect the premises. ${ }^{292}$ Although meant as a balancing mechanism, these provisions also arguably violate the right to import under articles 27 and 28 of TRIPS.

The amendment also incorporated changes in the compulsory licensing provisions. Although TRIPS allows for limited compulsory licensing under article 32, the United States objected to specific instances leading to compulsory licensing. ${ }^{293}$ Hence the second amendment introduced section $95 \mathrm{~A}$ in the Indian patent legislation. ${ }^{294}$ This section provided for the termination of compulsory license provided the controller is satisfied that circumstances enabling the license cease to exist and will not recur. ${ }^{295}$ Unlike in the Patent Act of 1970, refusals by a patentee to grant a license ceased to be deemed unreasonable. ${ }^{296}$ An applicant for compulsory license should prove that the patentee was approached with reasonable terms for a license. ${ }^{297}$

Section 107A(b) dealt with parallel imports. ${ }^{298}$ Importation of a patented product from a "person . . . duly authorized by the patent" is not infringement. ${ }^{299}$ A framework of appeals has been introduced ${ }^{300}$ as required under the Patent Cooperation Treaty of 1970, which India signed in $1998 .{ }^{301}$ Therefore, the controller's decisions can be appealed before an appellate

288. The Department of Health is a department of the Ministry of Health and Family Welfare.

289. Notification G.S.R. 834(E), GAZETTE OF INDIA, Oct. 24, 2000, at 35 ("The following draft of certain rules further to amend the Drugs and Cosmetics Rules, 1945, which the Central Government propose to make, after consultation with the Drugs Technical Advisory Board, in exercise of the powers conferred by sections 12 and 33 of the Drugs and Cosmetics Act, $1940 \ldots$...).

290. Id. at 36-39.

291. Id. at 40.

292. Id. at 46.

293. Mehta \& Chavda, supra note 237, ๆ 91.

294. Patents (Second) Amendment Bill $\S 44$.

295. Id.

296. Id. \$39(b).

297. Id. \& 36 .

298. Patents (Second) Amendment Bill $\S 51$.

299. Id.

300. Id. § 54 .

301. Patent Cooperation Treaty, June 19, 1970, 28 U.S.T. 7645. 
board before reaching the courts. ${ }^{302}$ This laudatory move will restrict parallel imports in tune with article 28(1) of TRIPS.

This second bill was not passed by the Rajya Sabha and was therefore referred to the select parliamentary committee. ${ }^{303}$ The committee examined the bill and sought further understanding of the issues. ${ }^{304}$ The committee scheduled a tour to various countries, including Brazil, Argentina, ${ }^{305}$ China, ${ }^{306}$ Japan $^{307}$ Korea $^{308}$ and Canada, ${ }^{309}$ to discern the best practices. ${ }^{310}$ In the meantime, the WTO met in Doha, where developing countries gained more concessions. ${ }^{311}$ After the Doha Declaration, the Joint Parliamentary Committee rewrote the bill incorporating the Doha safeguards. ${ }^{312}$ The revised bill did not incorporate the product patent regime. The Rajya Sabha passed the bill on May 9, 2002, and the Lok Sabha on May 15, 2002. ${ }^{313}$ India hopes to incorporate the product patent regime through a third amendment before January $1,2005 .^{314}$

302. Patents (Second) Amendment Bill, § 54.

303. Press Release, National Working Group on Patent Laws and Public Interest Legal Support and Research Centre, Publications 2002-Publication 16 (2002), at http://www.patentmatics.com/pub2002/pub16.htm (last visited Mar. 13, 2003). This is the general procedure followed for bills rejected by the upper house. See supra note 252.

304. See supra note 252.

305. Brazil and Argentina are also developing countries and have problems similar to India's. Mario Osava, Health-Latam: AIDS Threatens Industrial Property in Form of Patents, INTER PRESS SERVICE (Nov. 10, 2000) at http://www.aegis.com/news/ips/2000/IP001106.html (last visited Mar. 13, 2003).

306. The committee wanted to understand the reason for increased foreign investments in China, although China has the same disadvantages as India. Ragavan, supra note 110 .

307. The committee wanted to understand Japan's success in enabling transfer of technology before amending the laws. Id.

308. In 1982 Korea entered into an Agreement with the U.S. to provide patent protection for pharmaceuticals and defaulted on that Agreement. See Theresa Beeby Lewis, Patent Protection for the Pharmaceutical Industry, 30 INT'L LAW. 835, 863 (1996).

309. The committee sought to understand how the Canadian government caters to its generic drug industry. Ragavan, supra note 110.

310. Id. The tour of the parliamentary committee delayed the submission of the report. $I d$.

311. Declaration on TRIPS Agreement and Public Health at Qatar, 2001, WTO Fourth Ministerial Conference, WT/MIN(01)/DEC/1 (01-5859), (Nov. 9-14, 2001), available at http://www.wto.org/english/thewto_e/minist_e/min01_e/mindecl_trips_e.htm.

312. Id. The safeguards in this Declaration allowed members to initiate compulsory licensing of patented drugs in national emergency. Id. I 5(b). A public health crisis was deemed as a national emergency warranting the use of compulsory licensing provisions. Id. I 5(c).

313. Patent Bill Passed, THE HINDU, May 15, 2002, at National, available at http://www.hinduonnet.com/thehindu/2002/05/15/stories/2002051501381300.htm (last visited Mar. 17, 2003).

314. Id. This is the maximum time allowed under article 70 clauses (8) and (9) of TRIPS for India to embrace a product patent regime. TRIPS Agreement, supra note 8, arts. 70(8)-(9). 


\section{HINDRANCES AFFECTING DEVELOPING NATIONS FROM EMBRACING TRIPS}

The development of patent policies discussed in earlier sections of this article depicts a huge gap in patent familiarity between developed and developing nations. Additionally, the economic and epidemic conditions of developing nations warrant a certain focus in patent policy. Under comparable circumstances, developed nations have preferred similar policy options. The following discussion identifies hindrances affecting the ability of developing nations to introduce a sophisticated patent policy as required under TRIPS.

\section{A. Missing Basic Requirements to Enforce TRIPS}

\section{Time Frame}

Historically, developed nations needed approximately 150 years to establish a patent regime as detailed in Part III. Europe and the United States have benefited from their patent friendliness since the $1700 \mathrm{~s}$. However, a century of experimenting with patent policies was required before the current patent regime evolved. In contrast, most developing countries, including India, Bangladesh, Pakistan, Egypt, and several African countries, became independent only as late as the mid-1900s. ${ }^{315}$ Patent policies were introduced in these countries during the $1900 \mathrm{~s}^{316}$ - a century

315. The First Declaration of Independence of Bangladesh was made on March 25, 1971. Virtual Bangladesh, History, Declaration of Independence, at http://www.virtualbangladesh. $\mathrm{com} /$ history/declaration.html (last modified Jan. 22, 2003). Pakistan obtained its independence in August 1947. 123IndependenceDay.com, Pakistan Independence Day Celebrations, at $\mathrm{http} / / \mathrm{www} .123$ independenceday.com/pakistan/independence/day (last visited Mar. 8, 2002). Egypt was occupied by the British in 1882 and was given independence in 1922 . Egypt, History of Egypt, at http://www.touregypt.net/hfrench.htm and http://www.touregypt. net/hbritish.htm (last visited Mar. 8, 2003). Later it was occupied by the Italians and Germans during World War II, and re-conquered by the British. It was made a republic in the year 1953. See also Ruth L. Gana, Prospects For Developing Countries Under The TRIPs Agreement, 29 VAND. J. TRANSNAT'L L. 735, 737 (1996) (discussing the history of multilateral trading system and that "developing countries clearly remained on the periphery, their relationship to developed countries tainted deeply with mistrust stemming from the colonial experience").

316. Historically, remnants of trademarks and other intellectual property systems have been identified in developing countries like India and China. Several other developing nations have had various forms of intellectual property systems either directly or reminiscent of colonial past. See Ruth Gana Okediji, Copyright and Public Welfare in Global Perspective, 7 IND. J. GLOBAL 
after developed nations established patent policies. ${ }^{317}$ Yet, the TRIPS agreement forces developing countries to catch up and plunge into the current intellectual property system in a matter of only ten years. ${ }^{318}$

\section{Local Manufacturing vs. Trade}

Developed nations carved patent policies to improve indigenous industries and not to facilitate trade as highlighted in Part II. ${ }^{319}$ The Industrial Revolution and subsequent events resulted in the development of manufacturing and industrial capabilities in the developed nations. Patent policy was used to sustain and encourage industrial potential locally. ${ }^{320}$ Strengthening the indigenous industries automatically increased trade. This paved the way for the development of a patent policy commensurate with trade.

However, developing countries lack local manufacturing capabilities. Without aiding the development of indigenous industries, the WTO policy merely facilitates trade. Devoid of local manufacturing potential, mere trade will result in the loss of indigenous industries and increased dependence on foreign companies. ${ }^{321}$ This will stunt the economies of developing countries. Developing nations are currently not at the crossroads of industrialization, where it makes sense to promote patent policies. Since developing countries have nothing to trade and cannot afford to trade with developed nations, there is a lack of logic in thrusting the TRIPS patent policy onto these nations.

\section{Economic Gains}

Developed nations would not have promoted patent policies had they not borne economic promise. Studies on TRIPS, on the other hand, project a definite economic loss resulting from an immediate welfare loss in developing countries. ${ }^{322}$ Yet, developing countries are encouraged to embrace TRIPS. Leading scholars like Robert Sherwood have concluded

LEGAL STUD. 117, 147-48 (1999) (discussing the various forms of intellectual property systems as "European expansionism").

317. See discussion supra Part II.A.

318. See discussion supra Part II.B.1.

319. See discussion supra Part II.A.1.

320. See discussion supra Part II.A.1.

321. See generally Keith E. Maskus, Intellectual Property Challenges for Developing Countries: An Economic Perspective, U. ILL. L. REV. 457 (2001).

322. See Robert M. Sherwood, The TRIPS Agreement: Implications for Developing Countries, 37 IDEA 491, 493-95 (1997). 
that developing countries may not benefit in the short-run though there will be long-term returns. ${ }^{323}$ Edwin Mansfield concludes that developing countries will only benefit from foreign direct investment in the long-run. ${ }^{324}$ Professor Carlos Correa reiterates that even assuming an increase in exports, welfare losses will be considerable. ${ }^{325}$ Based on an empirical study in developing nations, Professor Maskus argues that as poor nations "adopt stronger patents their economies could be exposed to monopoly impacts with detrimental effects on their [] trade."326 Professor Maskus concludes that "the short-run impacts of TRIPS will be to redistribute income between countries, with most gains accruing to the United States and other technology developers." 327 He adds that "intellectual property protection will generate additional market power that could [actually] harm information users." 328 Only "[o]ver the longer term . . . technical change and growth in the technology importing countries could be improved" provided the stronger intellectual property regimes are "complemented with appropriate collateral policies and institutions.",329

Policies without immediate economic gain will upset the fragile economic and social balance in developing countries. Social and economic issues in developing countries are intertwined with trade issues. ${ }^{330}$ Developed nations need to address these realities in their entirety before expecting the already impoverished economies of developing nations to sustain a policy resulting in further loss. Importantly, government motivation is a key factor to introduce and implement policies successfully. Governments simply lack the incentive to canvass policies with the knowledge that the resulting welfare loss will deprive them of another chance to govern.

323. Id. "[T] $]$ he impact of the TRIPS Agreement on most developing countries is likely to be slightly negative in the short run (one to two years) and increasingly favorable as local firms and individuals begin to realize the potential benefits for their activities." Id. Sherwood, however, notes that TRIPS may be able to promote foreign investment, but will not be an aide in encouraging domestic research and development. Id. at 495, 508 .

324. Id. at 502 n.33 and accompanying test; see also Evelyn Su, The Winners and the Losers: The Agreement on Trade-Related Aspects of Intellectual Property Rights and Its Effects on Developing Countries, 23 Hous. J. INT'L L. 169 n.226 (2000).

325. Carlos Correa, intellectual Property Rights, The WTO and Developing COUNTRIES: THE TRIPS AGREEMENT AND POLICY OPTIONS 23 (2000) (emphasizing that losses have already begun to appear in developing nations).

326. Maskus, supra note 321 , at 464 .

327. Id. at 472 .

328. Id.

329. Id. See generally Keith E. Maskus, Intellectual Property Rights in the Global ECONOMY (2000) (providing a detailed discussion and empirical evaluation of the subject).

330. See Okediji, supra note 316 , at $117,125-44$ (discussing the complexity of the issues relating to trade and welfare, particularly in the context of developing nations). 
4. Internalization

In general, developed nations provide distinguished infrastructure and amenities to people resulting in a good lifestyle. Patent policies of the developed nations furthered economic gains resulting in a better lifestyle and thus caused people to accept such policies. "The core issue in developing countries is . . the need for infrastructure, the provision of basic human needs, the guarantee of basic human rights, and the upward mobility [of people]."331 The economies of developing countries face crises similar to what developed nations faced during the depression, including diseases, overpopulation, lack of infrastructure, and inadequate industrialization. "In light of such priorities, intellectual property rights, divorced from [the] immediate needs of a country" are a mere luxury. ${ }^{332}$ Developing nations need to reconcile fundamental infrastructures before furthering trade policies like the TRIPS patent policy. ${ }^{333}$ People in developed nations have steadily internalized patent policies over time. Patent friendly nations also experienced periods of patent mistrust during bad economies. The Supreme Court of the United States, as discussed in Part II, mistrusted patents during the Depression Era. ${ }^{334}$ Even after decades of enjoying the benefits of patents, the first reaction of the American state governments in bad economic conditions was to restrict patent rights. ${ }^{335}$

Experts in the area, like Professor Ruth Gana, argue that intellectual property rights are "a sub-set of a larger body of rights prescribed by public law." ${ }^{336}$ Professor Correa states that in the absence of other factors, intellectual property rights will not automatically be influenced positively. ${ }^{337}$ Therefore, if economic conditions deteriorate, the already poor lifestyle of the people will worsen. Food and drugs will become unaffordable. Internalization of patent policies by people will be difficult.

331. Gana, supra note 315 , at 771 .

332. Id.

To be taken seriously in developing countries, intellectual property rights must interact with existing social structures to promote indigenous technological innovation and capital development. Without the specific conditions of strong property systems, stable government, free market capitalism, and zealous protection of corporate interests, it is unlikely that modern intellectual property in and of itself has the potential to transform developing countries into the technology producers they aspire to become.

Id. at 738 .

333. Okediji, supra note 316 , at 188.

334. See discussion supra Part II.A.2.

335. See discussion supra Part II.A.2 and infra Part IV.E.

336. Gana, supra note 315 , at 771 .

337. CORREA, supra note 325 , at $44-45$. 
Hence, developing nations also rightfully require the time for people to internalize and ease into new policies.

\section{B. $\quad$ Proper Policies with Inadequate Procedures}

Unless proper procedures are established, mere policies will not bring about a change in the functioning of the patent system. Developing countries lack the knowledge of procedural rules and mechanisms required to implement sophisticated policies. Developed nations have to aid the developing nations in establishing supplementing procedures. The Indian and American claiming procedures are compared to chart how research and development are likely to be affected in developing nations.

\section{Claiming Requirements in India}

The Indian patent legislation provides that every patent application should have either a provisional ${ }^{338}$ or a complete specification. ${ }^{339}$ The applicant submits a complete specification within twelve months of filing the provisional specification. ${ }^{340}$ Every specification shall: 1) "describe the invention," and 2) "begin with a title [] indicating the subject-matter" of the invention. ${ }^{341}$ Every complete specification shall: 1) "fully and particularly describe the invention, [] its operation or use and the method" of performance of the invention; 2) "disclose the best method of performing the invention" known to the applicant; and 3) "end with a claim or claims defining the scope of the invention." 342

The terms "description of the invention" and "best method" are not statutorily defined. The only guideline to claim construction is in section 10(5) of the Patent Act of 1970. This section details that claims should be "clear" and "succinct" and be "fairly based on the matter disclosed in the specification." 343

338. Patents Act of 1970, 25 InDIA A.I.R. ManUAL 450, § 7(4) (2d ed. 1979). A provisional specification is a mere description of the nature of the invention and its intended manner of working. This can be submitted after the inventor is ready with a prototype. Id.

339. Id.

340. Id. $\S 9(1)$. If it is not so submitted, the application will be deemed abandoned. Id.

341. Id. $\S 10(1)$.

342. Id. $\S 10(4)$. Rules 14 to 20 of the Patent Rules of 1972 elaborate the requirements for drawings and models included within the specifications. Patent Rules, 1972 (India) (1972).

343. Patents Act of 1970, 25 India A.I.R. MANUAl 450, $\S 10(5)(2 \mathrm{~d}$ ed. 1979). 
Lack of adequate statutory definition leaves construction of specification and claims within the courts' domain. ${ }^{344}$ The Delhi High Court has held that claims should specify the nature of the invention as well as the particular and distinguishing feature of the invention. ${ }^{345}$ The title of the invention claimed has little consequence in controlling the claim. ${ }^{346}$ Additionally, the Bombay High Court held that the patentee should describe the nature and the limits of the claim with clarity. ${ }^{347}$ No additional guidelines supplement these broad rules of interpretation, which leaves unfettered discretion with the judiciary to construe specification and claims. Thus, claim construction is very subjective and unlimited in India.

\section{American Claims}

Claim construction is the heart and soul of the American patent system. 35 U.S.C. $\S 112$ provides the relevant statutory guidance. ${ }^{348}$ The United States Patent and Trademarks Office ("USPTO") supplements $\S 112$ with guidelines to govern claim drafting. ${ }^{349}$ Additionally, the Federal Circuit supplements claim interpretation techniques through its decisions. The American courts measure the scope of patent protection from the various claims.

For example, product-by-process claims describe the product by the process of production. ${ }^{350}$ The patent will be awarded for the product produced by the patented process. Jepson claims define the invention by reciting the admitted prior art in the preamble and by adding an "improvement" clause reciting the ambit of the invention. ${ }^{351}$ Functional or structural limitations are then incorporated to define the patent with precision. Functional claims describe the product by its function. ${ }^{352}$ The

344. Lallubhai Chakubhai Jariwala v. Chimanlal Chunilal and Co., 1936 A.I.R. 23 (Bom.) $99,99$.

345. Ram Narain Kher v. Ambassador Indus. New Delhi, 1976 A.I.R. 63 (Del.) 87, 88.

346. Raj Parkash v. Mangat Ram Choudhary, 1978 A.I.R. 65 (Del.) 1, 1.

347. Press Metal Corp. v. Noshir Shorabji, 1983 A.I.R. (Bom.) 144; see also Parkash, 1978 A.I.R 65 (Del.) 1, 1.

348. 35 U.S.C $\S 112(2000)$.

349. See, e.g., Utility Examination Guidelines, 60 Fed. Reg. 36,263 (July 14, 1995); see also Lisa A. Karczewski, Biotechnological Gene Patent Applications: The Implications of the USPTO Written Description Requirement Guidelines on the Biotechnology Industry, 31 MCGEORGE L. REV. 1043, 1064-66 (2000) (detailing the importance of these guidelines).

350. See ADELMAN ET AL., supra note $1, \S 11.2(\mathrm{~b})$, at 647 ; see also Atlantic Thermoplastics Co. v. Faytex Corp., 970 F.2d 834, 845-47 (Fed. Cir. 1992).

351. See AdELMAN ET AL., supra note $1, \S 11.2(\mathrm{~d})$, at 677.

352. 35 U.S.C $\$ 112(2000)$ (discussing the means plus function approach which is unique to the American system); see In re Donaldson Co., 16 F.3d 1189, 1193-96 (Fed. Cir. 1994). 
patent will vest on the product performing a specified function. Structural claim limitations, typically used for biotech inventions, describe the product structure. ${ }^{353}$ The means plus function claim limitations define the function and the means or mechanism enabling the product to perform the function. ${ }^{354}$ The patent vests on the product provided it performs the function using the means specified in the claim. ${ }^{355}$ Therefore, a product performing the same function with different means is eligible for another patent.

\section{Effect on Research and Development}

The ability of the enactment to cater to a wider range of inventions within the same product classification through claiming provisions is a mark of sophistication of the patent system. Such sophistication is acquired by a thorough understanding of the functioning of the patent system. TRIPS harmonizes patent systems, but without the supporting procedural backup, this harmonization will be pointless. Developing nations will lack the procedural and structural pillars of patent policies. Consequently, inventions distinguished through functional or structural additions will be denied patents in developing nations.

On the other hand, developed nations encourage inventions distinguished through functional or structural additions by using claim sophistication or patent doctrines. ${ }^{356}$ For example, in Dolly, Inc. v. Spalding \& Evenflo Cos., ${ }^{357}$ the patented device related to a portable, adjustable, child's play chair with a stable rigid frame with a seat and back panel. ${ }^{358}$ The claimed invention related to a portable, adjustable, child's play chair but did not have a stable, rigid frame. ${ }^{359}$ Instead, the seat and back panel of the device fit together to form a rigid frame. ${ }^{360}$ The court used the doctrine of equivalents and held that "a stable rigid frame assembled from the seat and back panels is not the equivalent of a separate stable rigid frame" set out in the claim language. ${ }^{361}$

353. See ADELMAN ET AL., supra note $1, \S 11.2(\mathrm{c})$, at 670-71.

354. Id.

355. Id.

356. See Graver Tank \& Mfg. Co. v. Linde Air Prods. Co., 339 U.S. 605, 607-09 (1950); Warner-Jenkinson Co. v. Hilton Davis Chemical Co., 520 U.S. 17, 17 (1997) (discussing the doctrine of equivalents).

357. 16 F.3d 394 (Fed. Cir. 1994).

358. Id. at 396.

359. Id. at 397.

360. Id. at 400 .

361. Id. 
In the case of In re Donaldson $\mathrm{Co}_{0 .}{ }^{362}$ the patent related to industrial airfiltering devices often referred to as "dust collectors."363 Claim one was an apparatus claim reciting an "air filter assembly for filtering air laden with particulate matter, said assembly comprising: [a plurality of elements]."364 On appeal, the patentee conceded that a single prior art reference (Swift) ${ }^{365}$ met every limitation in claim one except for the limitation of a "means, responsive to pressure increases in said chamber caused by said cleaning means, for moving particulate matter in a downward direction." 366 The Board held that the last limitation was also met by the prior art because Swift disclosed the recited function. ${ }^{367}$ On appeal, the Federal Circuit considered the issue en banc and unanimously reversed the Board's decision. ${ }^{368}$ The Federal Circuit reasoned that if the prior art does not disclose the same structure, or an equivalent structure, the claim element is not literally met and the claim is not anticipated under section $102 .{ }^{369}$ If the prior art does not provide a teaching, which renders the claimed structure or its equivalent obvious, the claim is not obvious under section $103 .{ }^{370}$ In essence, two dust collectors differentiated only by a single element have each been patented. Thus, similar products performing the same functions and manufactured by the same or similar processes are patentable in the United States by the use of appropriate claims. The law is dynamic enough to accommodate different patents for the same range of products with minor differences. This has provided the incentive for industries working in the same field to evolve and capitalize on the benefits.

A system that merely has a product patent regime (like the one contemplated for the developing countries under the WTO) without its complimentary procedural foundations will effectively block the patenting of products within the same range. In the above examples, patenting of one air-filtering device will effectively stop any other air filters from being patented; thus, it can stunt research and development. Therefore, a product

362. 16 F.3d 1189 (Fed. Cir. 1994).

363. Id. at 1190 .

364. $I d$. at 1191 (internal references omitted).

365. Id. at 1191-92. The Board relied solely upon the dust collector disclosed in United States Patent No. 3,421,295 and titled the Swift patent to affirm the Examiner's rejection of claim one. Id. The Swift dust collector embodied every element of the subject matter sought to be patented except for the "'means, responsive to pressure increases in said chamber caused by said cleaning means, for moving particulate matter in a downward direction'" Id. at 1192 (quoting claim one of the complaint).

366. Id. at 1191 .

367. Id.

368. Id. at 1197 .

369. Id.

370. Id. at 1189 . 
patent regime cannot be blindly introduced unless there is an adequate understanding of the nuances.

\section{Denial of Genuine Patents}

Introduction of the TRIPS regime in developing countries has the danger of excluding protection for new processes of making known products until supporting claiming techniques are introduced. Consequently, inventions patentable in developed nations by use of product-by-process claims may be unprotected in developing nations. This section examines how patenting of inventive processes is likely to operate in developing countries if TRIPS is established.

The use of product-by-process claims facilitates patenting of novel and non-obvious processes of making known products in developed nations particularly in the United States and Europe. In Atlantic Thermoplastics Co. v. Faytex Corp. ${ }^{371}$ the plaintiff owned patent containing process and product-by-process claims for a shock absorbing shoe innersole made from an elastomeric material and polyurethane foam. ${ }^{372}$ The issue related to innersoles with elastomeric heel inserts distributed by the defendant. ${ }^{373}$ The defendant bought the product from two separate manufacturers using separate manufacturing processes. ${ }^{374}$ The plaintiff's suit was against the defendant for infringing the patented process and, therefore, related to both the manufacturing processes. ${ }^{375}$ The Federal Circuit held that the process of the first manufacturer infringed the patent, as it contained all the claim limitations listed in Atlantic Thermoplastics' patent. The second manufacturer used a different process to achieve an indistinguishable product; thus, there was no infringement of product-by-process claim. ${ }^{376}$ The Federal Circuit overruled Scripps Clinic $^{377}$ by holding that a product claimed by a product-by-process description is only infringed when the allegedly infringing product is produced via the same process described in the claim. ${ }^{378}$ The court did not consider the issue relating to the doctrine of equivalence. In effect, this judgment allows the patenting of different processes of producing a known product by using the product-by-process

371. 970 F.2d 834 (Fed. Cir. 1992).

372. Id. at 834 .

373. Id. at 835 .

374. Id.

375. Id.

376. Id.

377. Scripps Clinic \& Research Found. v. Genentech, Inc., 927 F.2d 1565 (Fed. Cir. 1991).

378. Atlantic Thermoplastics, 970 F.2d at 838-39. 
claim. A careful study of Judge Rich's harsh dissent criticizing the Federal Circuit for refusing to rehear Atlantic Thermoplastics ${ }^{379}$ en banc reflects this understanding. ${ }^{380}$

The patent protection regimes of developing nations protect novel processes of producing known products although the product is not patent protected. $^{381}$ Both systems facilitate protection of innovative processes and encourage novel methods of producing known products.

TRIPS stipulates that members must award patents, "whether product or process, in all fields of technology.",382 A developing country signatory to TRIPS will have to extend product patent protection to previously excluded subject matter. For example, inventions relating to food, drugs, chemical processes, etc., will be protected by product patent protection in India. Developing countries do not use product-by-process claims and lack claimdrafting mechanisms for patenting inventive processes of patent protected products. Therefore, although novel processes are patentable under TRIPS, developing countries will lack the mechanism to facilitate such patents. This malady may result in generic drugs patentable in developed nations being unprotected in developing nations.

\section{A Need Not to TRIP}

Global welfare is never an excuse for local distress. Developed nations need to carefully estimate local economics before forging international policies. For example, in India only a mere $30 \%$ of the population has secured access to modern medication despite the aggressive development of the indigenous pharmaceutical industry. ${ }^{383}$ The introduction of TRIPS is likely to deprive even this $30 \%$ of access to drugs due to escalating costs. This section analyzes the importance of the pre-TRIPS patent policy and

379. 974 F.2d 1279 (Fed. Cir. 1992).

380. Id. at 1281 (Rich, J., dissenting) (stating that "innovative R \& D is not going to be encouraged by the rule just laid down by the Atlantic Panel').

381. Patents Act, $1970 \S 5$ specifically relates to inventions relating to food, medicines and chemicals, stating that "no patent shall be granted in respect of claims for the substances themselves, but claims for the methods or processes . . . shall be patentable." Id. Interestingly, the Atlantic Thermoplastics case related to a chemical process. $970 \mathrm{~F} .2 \mathrm{~d}$ at 835 .

382. TRIPS Agreement, supra note 8, at art. 27.

383. Interview by Pharmabiz.com with Ranjit Shahani, President of Pharmaceutical Producers Association of India (Dec. 6, 2001), at http://www.pharmabiz.com/ article/detnews 1 .asp?articleid $=11345$ \&sectionid $=42$; see also Pharmaceutical Research \& Manufacturers of America International, India: A Cautionary Tale on the Critical Importance of IP Protection, at http://www.phrma.org/international/ resources/12.04.2001.41.cfm (last visited Mar. 3, 2003). 
discusses the economics of pursuing the policy. Although India is used as a case study, the same arguments apply for every developing country.

Between 1947 and 1970, foreign multinationals dominated the Indian pharmaceutical industry. ${ }^{384}$ The Indian government's move in 1954 to develop an indigenous drug industry by establishing Hindustan Antibiotics Ltd. $^{385}$ was prompted by the density of disease in India. ${ }^{386}$ The patent policy of 1970 dramatically changed this condition. ${ }^{387}$ The present value of the Indian pharmaceutical industry at 70 billion rupees dwarfs the mere 100 million rupees in $1947 .{ }^{388}$ Currently, 20,000 pharmaceutical manufacturers are licensed in India. ${ }^{389}$ Of the 500 bulk drugs used within India, approximately 350 are manufactured within the country. ${ }^{390}$ The Indian pharmaceutical industry has emerged as a world leader in the production of several bulk drugs. ${ }^{391}$ Today, India is a major player in the international generic drugs market. India also emerged as a reliable exporter of the generic AIDS drugs during the South African AIDS crisis. ${ }^{392}$ Even the

384. See discussion supra Part II.C.1.

385. Hindustan Antibiotics Ltd. was founded in 1954. The company was established for job creation and manufacturing life-saving drugs. Currently, the company manufactures seventy-eight formulations and four bulk drugs. Hindustan Antiobiotics Ltd., at http://www.hindantibiotics.com (last visited Mar. 3, 2003).

386. See Sean Eric Smith, Opening Up to the World: India's Pharmaceutical Companies Prepare for 2005, Asia PACIFIC ResearCh Center Publication (Stanford Univ. Inst. for Int'l Studies, Working Paper, 2000), available at http://ldml.stanford.edu/iispubsearch.iis?database $=$ publ\&-layout=view\&-response $=$ viewpub.html\&-recordID $=35337 \&$-token.cntr=IIS \&token. acro=A/PARC\&-search; see also Ragavan, supra note 110.

387. See Ragavan, supra note 110.

388. Banerji, supra note 102 , at 80.

389. Indian Pharmaceutical Industry: An Overview, Pharmaceutical and Drug Manufacturers, available at http://www.pharmaceutical-drug-manufacturers.com/ pharmaceutical-industry (last visited Apr. 17, 2003).

390. Id.

391. See Martin Adelman \& Sonia Baldia, Prospects and Limits of the Patent Provisions in the TRIPS Agreement: The Case of India, 29 VAND. J. TRANSNAT'L L. 507, 525 (1996) (arguing that strong intellectual property protection will be in India's interest given its infrastructure in pharmaceutical production). Indian industry has emerged as a leader for the production of bulk drugs like sulphamethoxazole and ethambutol. Indian production accounts for nearly $50 \%$ of the world production. Several companies like Ranbaxy, Dr. Reddy's and Cipla have the potential to become billion dollar companies within the next few years. Id. But see J.H. Reichman, Compliance with the TRIPS Agreement: Introduction to a Scholarly Debate, 29 VAND. J. TRANSNAT'L L. 363, 374 (1996) (using the same data to argue that free-riding is a way for a developing economy to accumulate the skills and capital necessary to become innovative).

392. See Michael Waldholz \& Rachel Zimmerman, Bristol Myers Offers to Sell Two AIDS Drugs in Africa Below Cost, WALL ST. J., Mar. 15, 2001, at B1 (explaining that although Bristol Meyers lowered their prices by $55 \%$, it was still higher than the price of Indian drug companies); see also Robert Block, Cipla Tries to Skirt South Africa AIDS-Drug Battle, WALL ST. J., Mar. 9, 2001, at B6. 
United States considered importing generic drugs from India during its recent Anthrax crisis. ${ }^{393}$

Most importantly, the patent policy of 1970 catered to the needs of the Indian poor. Drug prices in India are among the cheapest in the world and are affordable for the general population. On average, drugs manufactured in India are more than $100 \%$ cheaper than the same drugs in the United States. $^{394}$ Even generic drugs manufactured in the United States are comparatively more expensive. ${ }^{395}$ The government of India has achieved the constitutional mandate of social and economic balance by setting a maximum sale price while still leaving room for a reasonable profit. The Indian government assures availability of patented drugs in the market by retaining the power to compulsory license. Interestingly, the Indian government has never used the compulsory licensing provision since the enactment of the patent legislation.

However, the economic brunt of the 1970 patent policy has not escaped India. Multinational companies, once major players, became reluctant to sell in India. ${ }^{396}$ By 1997, multinational companies accounted for less than $30 \%$ of bulks and $20 \%$ of locally produced formulations. ${ }^{397}$ Most multinationals complied with the minimum requirements necessary to

393. See Manu Joseph, Indian Cipro Copies Don't Pay Off, WIRED News (Nov. 8, 2001), at http://www.wired.com/news/medtech/0,1286,48153,00.html. The cost of cipro was $\$ .60$ per tablet eight years ago in India. The cost of cipro currently is $\$ .04$. Indian drug-makers export the generic version of cipro to Russia, Brazil, Southeast Asia, and the Middle East at highly competitive prices. Id.

394. See David Scondras, A Visit to India-Drug Prices, Research and Global Access, BEING ALIVE, May 1999, at http://www.beingalivela.org/news0599/0599\%visittoindia.html (arguing that drug prices in India are between 1000 to $4000 \%$ cheaper than the prices in the United States). For example, the price of the antibacterial drug Norfloxacin at $\$ .06$ in India compares to $\$ 12.26$ in America. The anti-inflammatory drug Piroxicam costs less than $\$ .05$ in India as against the American price of $\$ .115$. AZT (azidovudine), a drug retailed for $\$ .0582$ per $300 \mathrm{mg}$, is sold in India in capsule form for $\$ .0142$; see also Banerji, supra note 102, at 83 .

395. See generally Scondras, supra note 394 (arguing that American generic drugs are also more expensive). Hytrin, a sophisticated anti-hypertensive, is sold in India for $\$ .07$ a tablet. A month's supply of the drug costs about $\$ 4.20$. This is the final price after adding a $200 \%$ profit as allowed under the drug price control order. In the United States (Boston), the same drug from the same company costs $\$ 44.48$; Ranitidine (the generic equivalent of Zantac, an $h-2$ blocker which reduces stomach acid) costs $\$ .42$ for $150 \mathrm{mg}$ in the United States. The exact same product in India costs $\$ .0179$. Scondras notes that the American generic drug is $2346 \%$ more expensive. Id. ๆๆ $1-3$.

396. Multinational companies also could not match the price of the local companies. There was no market for the patented versions when the locally manufactured generic versions were sold at $100 \%$ below cost.

397. Jean Q. Lanjouw, The Introduction of Pharmaceutical Product Patents in India: "HeARTLESS EXPloitation of THE POOR AND Suffering?" 4 (Nat'l Bureau of Econ. Research, Working Paper No. 6366, 1998). 
maintain presence in the Indian market (such as producing simple formulations from imported bulks), while awaiting stronger patent protection. ${ }^{398}$ As discussed in Part II, the government responded by steadily reducing price controls on drugs. ${ }^{399}$

However, the limited purchasing power of the Indian public compels cost effectiveness of pharmaceuticals. ${ }^{400}$ Given this impediment, the recent amendments to the patent legislation should only marginally affect drug prices. ${ }^{401}$ India has to concentrate on local welfare until appropriate means are established for the entire population to access drugs.

\section{E. Patent Policies of Developed Nations Under Comparable Circumstances}

Developed nations have historically embraced protectionist policies and weak patenting regimes to foster industrial development, followed by strong patent regimes to sustain industrial growth. The Ayyangar Report ${ }^{402}$ in 1959 pointed out that Germany's weak patent protection enabled the growth of the German chemical industry. ${ }^{403}$ The U.K. in 1852 and the United States in 1873 embraced protectionist policies in economies comparable to that of the developing nations as discussed in Part II. ${ }^{404}$ Canada refused to grant pharmaceutical product patents until 1987 and maintained compulsory licensing of pharmaceutical patents until $1991 .^{405}$ The Japanese patent laws of the 1950s, which governed the first twenty-year period in Japan following World War II, provided only for process patents for pharmaceutical industry. ${ }^{406}$ As late as 1987 , Japan was included along with Mexico, Brazil, Taiwan, and Korea in the list of fifty-four countries cited by

398. See Smith, supra note 386.

399. See supra notes 153-159 and accompanying text. In 1970, most drugs were under price control and by 1984 this was reduced to 347 drugs, and to 163 drugs in 1987 . In 1994, only 73 drugs remained under price control. See supra notes 153-159 and accompanying text.

400. Koshy, supra note 154 \47.

401. Id.

402. RAJAGOPALA-AYYANGAR REPORT, supra note 129 , at 24.

403. Id.

404. See supra Part II. America amended the patent statute in 1873 and later in 1952 . The patent legislation in England was enacted to encourage industries and developing local manufacturing.

405. Gerald J. Mossinghoff, Research-Based Pharmaceutical Companies: The Need for Improved Patent Protection Worldwide, 2 J.L. \& TECH. 307, 320-21 (1987).

406. Koshy, supra note 154, I 51. After the Japanese parliament determined that the pharmaceutical industry lacked technical development capabilities, the government protected these industries from foreign competition. This enabled the Japanese pharmaceutical industry to create manufacturing capabilities and become highly competitive. Id. 
the United States International Trade Commission for inadequate patent protection. $^{407}$ Japan introduced pharmaceutical product patents only in 1975 and still retains the compulsory licensing provisions. ${ }^{408}$ Even the United States follows the strategy of establishing a patent regime to foster industrial development and sustains growth with a strong patent regime.

The development of biotech patents in the United States is the contemporary example showing that stringency in patent policies has been commensurate with industrial development. The case of Diamond $v$. Chakrabarthy ${ }^{409}$ in 1972 provided for the development of biotech industries by holding that microorganisms are patentable subject matter under Title 35 U.S.C. $\S 101$. A more positive attitude towards biotech patents was witnessed in Amgen v. Chugai. ${ }^{410}$ In Amgen, the court held that conception of a chemical compound cannot occur unless the inventor has "a mental picture of the structure of the chemical, or is able to define it by its method of preparation, its physical or chemical properties, or whatever characteristics sufficiently distinguish it." ${ }^{411}$ Thus, the court enunciated the doctrine of simultaneous conception and reduction to practice. $^{412}$ Additionally, the court did not invoke the requirement that the actual DNA sequence be disclosed, but only that the DNA be defined in a manner distinguishing it from other chemicals along with a description of how to obtain it. ${ }^{413}$ This left the possibility of adequately describing a particular DNA sequence even when the inventor is unaware of its structure. ${ }^{414}$

The case of In re Deuel ${ }^{415}$ was one of the first steps the Federal Circuit took to reduce application standards for biotech patents in favor of applicants. ${ }^{416}$ In Deuel, the court further reduced the standards from Amgen

407. Alan S. Gutterman, The North-South Debate Regarding the Protection of Intellectual Property Rights, 28 WAKE FOREST L. REV. 89, 102 (1993).

408. Koshy, supra note 154, \ 52 .

409. 447 U.S. 303 (1972).

410. 927 F. 2d 1200 (Fed. Cir. 1991).

411. Id. at 1206 .

412. Id. The court stated that "[c]onception is the "formation in the mind of the inventor, of a definite and permanent idea of the complete and operative invention, as it is hereafter to be applied in practice."' Id. (internal citations omitted). Thus, the doctrine of simultaneous conception and reduction to practice evolved to determine priority of invention. An inventor may be unable to establish conception until the invention has been reduced to practice through experimentation. Id.

413. Id.

414. The court merely required that the DNA sequence be disclosed in a manner that sufficiently distinguishes it; the DNA sequence could be defined by its actual structure as well as its method of preparation. Id.

415. 51 F.3d 1552 (Fed. Cir. 1995).

416. Id. at 1557-60; see also In re Bell, 991 F.2d 781, 784-85 (1993). 
by minimizing the non-obviousness requirement. ${ }^{417}$ The Federal Circuit achieved this by defining the legal test of prima facie obviousness. The invention in Deuel related to isolated and purified DNA and cDNA molecules encoding heparin-binding growth factors (HBGF). ${ }^{418}$ HBGFs stimulate mitogenic activity and facilitate repair of damaged tissue. ${ }^{419}$ Structural claims were used for the patent application. ${ }^{420}$ The patent examiner had cited a combined teaching of the Bohlen and Maniatis prior art references to reject Deuel's application as prima facie obvious under section $103 .{ }^{421}$ The court considered "whether the combination of a prior art reference teaching a method of gene cloning, together with a reference disclosing a partial amino acid sequence of a protein, may render DNA and cDNA molecules encoding the protein prima facie obvious under section 103."422 The court held that structural similarity between prior art compounds and the claimed compound may provide a basis for an obviousness rejection because the structural similarity establishes the motivation to make the claimed compound. ${ }^{423}$ However, the court held that although a general method of isolating DNA molecules is known, a specific DNA molecule isolated is prima facie non-obvious and patentable. ${ }^{44}$ The impact of this decision made obviousness rejection less common for biotechnology patents. ${ }^{425}$

Deuel enabled patenting of miniscule inventions by lowering the obviousness bar. ${ }^{426}$ Economically, this lowering of the obviousness standard boosted the biotech companies. ${ }^{427}$

417. Deuel, 51 F.3d at 1557-60. Deuel isolated and purified heparin-binding growth factors (HBGF) from bovine uterine tissue, and determined the first twenty-five amino acids of the N-terminal sequence. Id. at 1555 . Deuel then isolated cDNA encoding for the bovine HBGF by screening the bovine DNA library with an oligonucleotide probe. Id. Deuel purified the cDNA and found that its sequence consisted of 1196 nucleotide base pairs. Id. The bovine cDNA was then used as a probe to isolate and purify human placental HBGF. Id. Deuel isolated, purified, and then determined the sequence of the human placental cDNA which consisted of 961 nucleotide base pairs. Id. With this knowledge, Deuel predicted the complete amino acid sequence of the human placental HBGF. Id.

418. Id. The claims on appeal were independent. See Id. at 1555.

419. Id at 1554 .

420. Id.

421. Id. at $1555-56$.

422. Id. at 1557 .

423. $I d$. at 1558 .

424. Id at 1559. "[T]he existence of a general method of isolating cDNA or DNA molecules is essentially irrelevant to the question whether the specific molecules themselves would have been obvious, in the absence of other prior art that suggests the claimed DNAs." Id.

425. Shraddha A. Upadhyaya, The Postmodern Written Description Requirements: An Analysis of the Application of the Heightened Written Description Requirement to Original Claims, 4 MinN. Intell. Prop. Rev. 65, 107-09 (2002).

426. ADELMAN ET AL., supra note 1 , at 517. 
On the one hand, based on prior art knowledge, the biotechnologist knows that sequencing around twenty amino acids is sufficient to obtain the cDNA sequence that codes for a particular protein, absent unforeseen difficulties. On the other hand, under current law, the expected product of this scientifically obvious manipulation is legally unobvious and thus patentable. ${ }^{428}$

Biotech companies scrambled to obtain patents by innovating and inventing in biotechnology and pharmaceuticals. ${ }^{429}$ The Deuel decision greatly helped the United States become the leader in biotechnology patent applications and prosper from a rapidly growing biotechnology industry. ${ }^{430}$ "The Chakrabarty and Deuel decisions were rendered in order to spur biotechnology innovation and progress." ${ }^{431}$ The result was a proliferation of intellectual property rights in biomedical research. However, the disadvantage was the under-use of the resources by people as too many owners blocked each other. ${ }^{432}$ The biotech industry was faced with "a spiral of overlapping patent claims in the hands of different owners." 433 These realities mandated that the free-for-all biotechnology patent application be capped. ${ }^{434}$ This cap came in the form of the heightened written description requirement in Regents of the University of California v. Eli Lilly \& Co. ("Eli Lilly"). ${ }^{435}$ This case bridged the gap created by Deuel by using the

427. See Sara Dastgheib-Vinarov, A Higher Nonobviousnes Standard for Gene Patents: Protecting Biomedical Research from the Big Chill, 4 MARQ. INTELL. PROPER. L. Rev. 143, 178 (2000); Upadhyaya, supra note 425, at 109.

428. Anita Varma \& David Abraham, DNA Is Different: Legal Obviousness and the Balance Between Biotech Inventors and the Market, 9 HARV. J.L. \& TECH. 53, 78 (1996).

429. Dastgheib-Vinarov, supra note 427, at 143.

430. Upadhyaya, supra note 425, at 109.

431. Id.

432. Michael A. Heller \& Rebecca S. Eisenberg, Can Patents Deter Innovation? The Anticommons in Biomedical Research, SCI. MAG., May 1, 1998, available at http://www.science mag.org/cgi/content/full/280/5364/698.

433. Id.

434. Upadhyaya, supra note 425, at 109.

[B]etween 1990 and 1998, the total number of biotechnology patents granted to U.S. corporations has quadrupled. In contrast, between 1990 and 1998 , the total number of patents issued increased by about sixty percent. This large disparity is cause for concern. It suggests that the biotechnology industry is using the relaxed nonobviousness standard to obtain genomic patents simply for corporate gain.

Dastgheib-Vinarov, supra note 427, at 165.

435. 119 F.3d 1559, 1566-69 (1997); Upadhyaya, supra note 425, at 109. The University of California ("UC") brought suit in 1990 against Eli Lilly alleging infringement of two patents relating to recombinant DNA technology. Eli Lilly, 119 F.3d. at 1562 . Specifically, the patents related to recombinant plasmids and microorganisms that produce human insulin. Id. Persons unable to produce insulin suffer from diabetes. Id. Prior to recombinant technology for 
written description requirement to limit the overly-broad biotechnology patents of the Deuel rule. ${ }^{436}$

Eli Lilly curbed the race for biotech patents by holding that a generic description of the genus, such as "vertebrate insulin cDNA" or "mammalian insulin cDNA," is an inadequate written description. ${ }^{437}$ A generic written description distinguishes the claimed genus only by function. ${ }^{438} \mathrm{~A}$ functional definition is insufficient to define the genus because it merely indicates what the gene does, rather than what it is. Genes should be specifically defined. The structural features commonly possessed by members of the genus distinguishing them from others should also be defined. Thus, the court articulated the "precise definition" test. ${ }^{439}$ The Federal Circuit held that an adequate written description of a DNA molecule should be comprised of "'a precise definition, such as by structure, formula, chemical name, or physical properties,' not a mere wish or plan for obtaining the claimed chemical invention." heightened specificity requirement, a genus defined entirely by function is an inadequate written description of the specification. ${ }^{441}$ Prior to Eli Lilly, the Federal Circuit, in Fiers v. Revel, ${ }^{442}$ had created an exception to the rule that a claim included in the application cannot be rejected for lack of

producing human insulin to treat diabetes, animal insulin was used, which caused allergic reactions. Id. The ' 525 patent issued from an application filed in 1977. Id. The ' 525 patent related to proinsulin ("PI") and preproinsulin ("PPI") cDNA sequences in rats. Id. The "740 patent issued from an application filed in 1979. Id at 1563 . The " 740 patent covered human PI and PPI cDNA sequences, and tailoring techniques for the insertion of human PI cDNA into recombinant plasmids. Id. Eli Lilly produced human PI by using semi-synthetic DNA to produce a cleavable fusion protein. Id. The produced fusion protein consists of a bacterial protein, a cleavable linkage having a single methionine residue and human PI. Id. The human PI was obtained by cleaving it from the fusion protein. The district court ruled that claims 1,2 , and 4-7 in the ' 525 patent were invalid under section 112 , paragraph 1 because the specification did not provide an adequate written description of the cDNA covered in the claims. Id. The Federal Circuit affirmed, basing its holding upon lack of written description. Id. at 1569.

436. Eli Lilly, 119 F.3d at 1567.

437. Id. at 1568 .

438. Lisa A Karczewski, Biotechnological Gene Patent Applications: The Implications of the USPTO Written Description Requirement Guidelines on the Biotechnology Industry, 31 MCGEORGE L. REV. 1043, 1078 (2000).

439. Eli Lilly, 119 F.3d at 1566, 1567 (quoting Fiers v. Revel, 984 F.2d 1164, 1171 (Fed. Cir. 1993)).

440. Id. at 1567 (quoting Fiers, 984 F.2d at 1171). An adequate writien description of a DNA molecule "requires more than a mere statement that it is part of the invention and reference to a potential method for isolating it; what is required is a description of the DNA itself." Id. at 1566-67.

441. Karczewski, supra note 438 , at $1078-79$.

442. 984 F. 2d 1164 (Fed. Cir. 1993). 
description. ${ }^{443}$ The Fiers court demanded specificity by holding that "while one does not need to have carried out one's invention before filing a patent application, one does need to be able to describe that invention with particularity." ${ }^{444}$ This rule was used effectively in the Eli Lilly case.

\section{F. $\quad$ A Post-September 11th Impression on Patents}

The center of the global debate revolves around whether poverty and density of diseases are adequate reasons warranting a more accommodating patent regime. Developing nations traditionally support the argument. Out of business interests, developed nations have been forced to reject the arguments of the developing countries. The developed nations export goods and services across the world. For example, in 1989 alone, estimates of United States "exports of goods and services embodying intellectual property amounted to nearly $\$ 60$ billion." ${ }^{, 45}$ Therefore, intellectual property policies of developing nations impact heavily on business interests of developed nations. ${ }^{446}$ However, developed nations are likely to choose the same policy options pursued by developing nations in comparable circumstances. The United States government's reactions to the anthrax crisis, and the American state governments' ("State") reactions to drug prices under weak American economic conditions, strengthen the above argument.

\section{Anthrax Crisis}

The first case of anthrax in the United States was reported on October 4, $2001{ }^{447}$ By November 2, 2001, the number of anthrax cases increased to ten. $^{448}$ This increase necessitated immediate supply of anthrax drugs at an affordable cost. The spread of anthrax was directly linked to bioterrorism caused by the intentional release of bacillus anthracis spores. ${ }^{449}$ As fear gripped the North American continent, the United States and Canada took significant steps to make the anthrax drug affordable to the public. Public networks advised the people who panicked in the face of bioterrorism to

443. Id. at 1171; ADELMAN ET AL., supra note 1, at 611.

444. Fiers, 984 F.2d at 1169.

445. Pechman, supra note 5, at 183.

446. Id.

447. John A. Jemigan et al., Bioterrorism-Related Inhalation Anthrax: The First 10 Cases Reported in the United States, EMERGING INFECTIOUS DISEASES, Nov.-Dec. 2001, at 933, 934, available at $\mathrm{http}: / / \mathrm{www} . c d c . g o v / \mathrm{ncidod} / \mathrm{EID} / \mathrm{vol} 7 \mathrm{no6} / \mathrm{jernigan} . \mathrm{htm}$.

448. Id.

449. Id. 
take the affordable generic doxycycline. ${ }^{450}$ Meanwhile, Canada, a long and a trusted ally of the United States, canvassed the generic drug market. ${ }^{451}$ The United States considered the option of compromising business interests by buying generic versions of ciprofloxin from India. ${ }^{452}$ The possibility of importing low cost generic ciprofloxin from India was debated. ${ }^{453}$ The United States government contemplated federally appropriating the Bayer Inc., patent in ciprofloxin to manufacture the drug. ${ }^{454}$ This federal appropriation of intellectual property rights is termed compulsory licensing in developing countries. ${ }^{455}$ The steps taken by the United States and Canada were meant to produce the same effect produced by the drug price control order in India. ${ }^{456}$ A mere sixty cases of one infectious disease moved these patent-pillar nations to compromise business interests for public health. Developing countries house a sizable percentage of population with various diseases. Expecting developing countries to place the business interests of developed nations ahead of local public health issues is impractical.

\section{Price Control by the States}

The economic downfall during the Bush administration dried the tax revenues of the States. ${ }^{457}$ The decreased tax revenues left the States the choice of either providing less funds for state programs catering to the poor

450. E.g., Mellinda T. Willis, Officials Move Toward Doxycycline as First-Line Anthrax Treatment, ABC NEws.COM, Oct. 30, 2001, at http://abcnews.go.com/sections/living/ DailyNews/doxycycline011030.html.

451. See Amy Harmon \& Robert Pear, Canada Overrides Patent for Cipro to Treat Anthrax, N.Y. TimES, Oct. 19, 2001, at A1 (reporting that Canada overrode Bayer's patent for ciprofloxin and ordered a million tablets of the generic version from a Canadian company).

452. Joseph, supra note 393; see also Reuters Health, Indian Pharmaceutical Companies Prepared to Provide Generic Cipro (Oct. 25, 2001), at http://www.infectioncontroltoday.com/ hotnews/1ah2511050.html.

453. Joseph, supra note 393. Senator Charles Schumer approached Ranbaxy Laboratories, a generic drug company based in India, to check availability of the generic version of ciprofloxin at low cost. Id.

454. Id.

455. See id. Dilip Shah, a pharmaceutical consultant from India opines that the United States government's move to attempt to federally appropriate the Bayer patent in ciprofloxin is an admission of the position of developing countries that health considerations rank above business interests. Id.

456. See supra Part II.C.1.b (explaining that price control on drugs evolved to increase more accessibility of medication to the public).

457. Russell Gold et al., States Square Off Against Drug Firms in Crusade on Prices, WALL ST. J., Dec. 7, 2001, at A1. 
or confronting the cost of drugs. ${ }^{458}$ Florida made the first move in 2000 by urging drug companies participating in the Medicaid program to provide special rebates. ${ }^{459}$ Under federal law, pharmaceutical companies charge the same price to the States and preferred customers for Medicaid supplies. ${ }^{460}$ The States were left with the option of price control unless residents without drug coverage were offered discounts. ${ }^{461}$ Hence, Florida mandated drug companies to provide an additional $6 \%$ price discount. Maine restricted Medicaid access to expensive drugs. Maine held its position successfully in a challenge made by the drug companies. ${ }^{462}$ Michigan took a step further and proposed to set a low common denominator for drug prices. ${ }^{463}$ These measures were meant to protect public health by making drugs affordable.

The falling economy and the anthrax incidents tested the patent system at a difficult time. It is hard to argue that the system did not fail. Even the strongest proponents of patents like the United States stepped outside the box for a solution. Even the rich, patent-friendly nations consider patent restricting options to protect public health. Given this, TRIPS posits a strategically losing argument in forcing impoverished nations swamped by diseases to pay patented prices for drugs. In doing so, TRIPS provides primacy to business interests and ignores the public health perspective. To be workable, a patent policy needs to account for local needs and realities.

\section{UnREAlistic Estimates Costing the Developed Nation}

Developed nations have been unrealistic in estimating the workability of the patent policy in TRIPS. The effect of people's reaction to TRIPS patent policy in developing countries has been ignored in estimating its success. Although the United States emerged successful in encouraging the developing nations to embrace the TRIPS regime, it resulted in a heavy loss

458. Id.

459. Id. In August 2001, drug companies filed a case challenging the Florida program. Id.; see also Russell Gold et al., Pharmaceutical Industry Sues Michigan to Block Attempt to Cut Drug Prices, WaLl ST. J., Dec. 3, 2001, at A2.

460. Id.

461. Id.

462. See Pharm. Research \& Mfrs. of Am. v. Concannon, 249 F.3d 66, 85 (5th Cir. 2001) (challenging the Maine Rx program). A federal appeals court ruled in favor of Maine. Id. The U. S. Supreme Court, in October 2001, indicated that it may take up the case and has invited the Solicitor General to file briefs. Pharm. Research \& Mfrs. of Am. v. Concannon, 534 U.S. 947 (2001) (mem.); see also Pharm. Research \& Mfrs. of Am. v. Thompson, 251 F.3d 219, 221 (D.C. Cir. 2001) (contending that the federal government overstepped its authority in allowing Vermont seniors and uninsured residents not otherwise eligible for Medicaid to avail themselves of the program's low drug prices). The federal appeals court held in favor of PhRMA. Id.

463. See Gold, supra note 457. 
to the interests of the developed nations. The TRIPS patent policy has resulted in the loss of stature for the United States and the loss of markets for the pharmaceutical industry. Industries other than the pharmaceutical industry also lost since the heightened stress over the pharmaceutical issue enabled non-pharmaceutical sectors to quietly slip away. ${ }^{464}$ The following section analyzes the costs and benefits of enforcing the current patent policy in developing nations to audit the monetary and strategic losses for the developed nations. Further, the discussion centers on the issue of whether the developed nations exaggerated estimates and incorrectly weighed alternatives leading to the failure of the intellectual property policies in drugs.

\section{A. $\quad$ Voice of the People}

The reactions of people in developing countries are an important factor in the workability of the TRIPS patents policy. This section highlights the possible reactions and their effects on the successful implementation of the TRIPS patent policy.

\section{Cost of Drugs Leading to Parallel Markets}

The imposition of the patent policy in TRIPS will immediately increase the cost of drugs. For example, the anti-cancer drug vincristine, currently available for the equivalent of $\$ .40$ in India, will be sold for $\$ 8{ }^{465}$ Vast percentages of people live below a monthly income of $\$ 8$. The indigenous drug industry will face a setback raising unemployment levels. Poverty coupled with unemployment will result in new and old drugs being denied to the needy because of cost. ${ }^{466}$ Lack of domestic industrialization will increase the cost of all other commodities. Amidst this, local patent applications will be low since scientists cannot be expected to become patent savvy overnight. Patented products from abroad will be affordable only to the rich, resulting in an even bigger divide between the rich and the poor.

464. For example, specified sectors in developing nations like the Indian computer industry have progressed enough to move towards a patent regime. These industrial sectors would not have directly affected the general public and actually presented a higher chance for successful implementation. See discussion infra notes 564-565.

465. Banerji, supra note 102 , at 83.

466. Interview by the Trade and Development Centre with O.P. Grover, Director, Indian Drug Manufacturers Association, B.K Raizada, Vice President, Ranbaxy Laboratories Limited, and Ajit Yadav, Legal Services Director, Ranbaxy Laboratories Limited, at http://www.itd.org/issues/india5a.htm (last visited Feb. 14, 2003). 
The natural corollary is for the development of alternate markets to cater to the millions of needy people. The Indian drug industry itself evolved as a reaction to the unaffordable cost of foreign drugs. Even doctors in India prefer to prescribe the generic drug alternative to high cost patented drugs. ${ }^{467}$ Faced with an ailing patient with no means of affording the patented product, medical practitioners in developing nations will rarely refrain from providing the generic substitute. ${ }^{468}$ Ironically, the development of an alternate market is precisely what the TRIPS patent policy was designed to stop. Theoretically, it can be argued that increasing the implementation will eliminate pirating markets. Realistically, however, such attempts in developing countries will only lead to corruption. ${ }^{469}$

\section{Unrest in Developing Nations}

A future bonanza of increased domestic and foreign investment will be inconsequential to people unable to afford a medication to cure an ailment. If people are unable to accommodate the increased cost, there is potential for unrest to restore original policies. Several countries already have witnessed such unrests turning into vigorous protests. ${ }^{470}$ Protests against Monsanto $^{471}$ and PepsiCo ${ }^{472}$ in India increased the hostility of people and restricted growth. The protests in India triggered several protests against Monsanto in Philippines and Bangladesh. ${ }^{43}$ There were also several protests against Monsanto in Brazil based on the intellectual and environmental issues. ${ }^{474}$ These protests have increased the hostility of

467. Koshy, supra note $154, \llbracket 48$.

468. Id.

469. See Harvey E. Bale Jr., Patent Protection And Pharmaceutical Innovation, 29 N.Y.U. J. INT'L L. \& POL. 95, 100 (1996-1997). Bale argues that "inadequate intellectual property protection is really disguised protectionism for local industry." Id. Such protection is another basis for the corruption of public officials. Id.

470. Henrique Freire de Oliveira Souza, Genetically Modified Plants: A Need for International Regulation, 6 ANN. SURV. INT'L \& COMP. L. 129, 142-44 (2000).

471. See Institute for Global Communications, Monsanto's Cremation Starts In Karnataka, (Nov. 28, 1998), at http://liberated.tao.ca/monsantocremation.htm. The farmers lobby in India was termed "Operation Cremation Monsanto." This lobby accused Monsanto of trying to withhold information from the farmers. Id.

472. Sakuntola Narasimhen, Tandoori v. Kentucky Fried, Multinational MONitor (January/February 1996), at http://multinationalmonitor.org/hyper $/ \mathrm{mm} 0196.03 \mathrm{html}$ (last visited Mar. 17, 2003).

473. Institute for Global Communications, Thousands of Asia Farmers May "Evict" Monsanto in Philippines, (Aug. 22, 2002), at http://www.organicconsumers.org/monsanto/ asiaeviction.cfm.

474. See Freire de Oliveira Souza, supra note 470, at 155-56. On June 15, 1998, "Monsanto initiated the process for the commercial exploitation in Brazil of the Soy Roundup 
people and restricted the growth of the companies and the countries housing them. The unrest created by the protests influences government stability and stunts investment opportunities. ${ }^{475}$ The object of establishing the WTO to further trade will be defied if trade between the developed and developing countries is adversely affected.

\section{Pressured Third World Governments}

Governments in third world countries can do very little to enforce policies rejected by the people. Frustrations generated by the inability to deal with issues will force governments to either ignore implementation or renounce the policy itself; both results are detrimental to the developed nations. Several developing nations like Brazil, India, and South Africa yielded initially to international pressures but later renounced the policy under local pressures. For example, the Brazilian Health Minister forced more concessions after threatening to compulsorily license patented drugs. ${ }^{476}$ Strong protests in New Delhi forced India to lead the campaign in Doha to gain concessions from the WTO. ${ }^{477}$ After a chapter full of begging, pleading, and reasoning with the world, South Africa renounced patents in pharmaceuticals at a stage when the Pretoria regime of South Africa was fully aware that the magnitude of the AIDS crisis forced the world to go with it. ${ }^{478}$

Ready." Id. at 155 . This is the "soy modified genetically for added tolerance to the pesticide glyphosate." Id. Monsanto applied for the relevant authorization from CTNBio-the Brazilian Patent Office. Id. On December 30, 1998, CTNBio, through an internal enactment (Instrucao Normativa No. 18, D.O. No. 250-E, de 30 de dezembro 1998), authorized the commercial exploitation of the Soy Roundup Ready by the Brazilian subsidiary of U.S. Monsanto Co.Monsanto do Brasil Ltda. Id. at 156. This led to several protests in Brazil. Id.

475. See supra notes $451-452,455$ and accompanying text. About 25,000 protestors marched the streets of New Delhi to oppose WTO negotiations that were underway resulting in severe political pressure on the government. This is quoted as the reason for the stand India took in Qatar. Helene Cooper \& Geoff Winestock, Poor Nations Win Gains in Global Trade Deal as U.S. Compromises, Wall ST. J., Nov. 15, 2001, at A1.

476. Consumer Project on Technology, Ministry of Health Announces Compulsory Licensing of Nelfinavir Patent (Aug. 22, 2001), at http://www.cptech.org/ip/ health/c/brazil/nelf0 8222001.html; see also Miriam Jordan, Brazil To Break Roche Patent On AIDS Drug, WaLl ST. J., Aug. 23, 2001, at A3.

477. See Helene Cooper \& Geoff Winestock, Poor Nations Win Gains in Global Trade Deal as U.S. Compromises, WALL ST. J., Nov. 15, 2001, at A1. The role of India's Commerce and Industry Minister, Murasoli Maran, was pivotal in the resulting negotiations in the WTO in the Qatar session. Murasoli Maran's strong stance was in part a result of the political pressures the government faced in India. Strong protests were also witnessed in India a few days before the WTO session. Id.

478. See Charlotte Denny, A Spoonful Of Sugar Will Not Help, The Guardian (Apr. 19, 2001), available at http://www.guardian.co.uk/aids/story/0,7369,475344,00.html; see also 
Trade and export issues have bestowed developed nations with a better bargaining position over developing countries. Advocating unfriendly policies will push developing countries into economic crisis and unrest. Developing countries subjected to international pressure on one side and public health crisis on the other will either isolate or rebel. This may result in the developed nations losing their hold over the developing nations. Finally, the world will create for itself more Afghanistans and Argentinas. ${ }^{479}$

\section{B. The Lost Winner}

The deceptive win of the developed nations in encouraging developing countries to participate in a patent regime resulted in a lose-lose situation for the developed and the developing nations. International issues forced America to soften its original stance towards developing nations, particularly vis-à-vis drug patents. ${ }^{480}$ America was characterized as the global villain and pushed to a defensive position. America had no alternative but to replenish its tarnished image. This section does not discuss the correctness of the characterization. It merely argues that the effort to replenish its tarnished image cost America heavily. This section examines the strategy to identify areas leading to a loss for the developed nations.

\section{Loss of Stature}

America has lost its powerful bargaining stature amidst developing nations.

\section{a. South Africa}

In 1996, South Africa highlighted the extent of AIDS and requested access to drugs. ${ }^{481}$ The then American trade representative, Mr. Papovich, treated it as a routine matter and asked South Africa to comply with TRIPS

Miriam Jordan, Brazil May Flout Trade Laws To Keep AIDS Drugs Free For Patients, WALL ST. J., Feb. 12, 2001 , at Bl.

479. These are examples of countries isolated because of economic and political instability.

480. John Donnelly, Brazil to Break AIDS Drug Patent, Boston GloBE, Aug. 23, 2001, at 51, available at http://www.globaltreatmentacess.org/content/press_release/a01/082301_BG _CL.html (last visited Mar. 13, 2003). These include the AIDS issues in South Africa, Thailand, Brazil and in other developing nations detailed in this paper. See supra Part II.C.

481. Helene Cooper et al., AIDS Epidemic Traps Drug Firms in a Vise: Treatment vs. Profits, Wall St. J., Mar. 2, 2001, at A1. 
immediately. ${ }^{482}$ Fearing trade sanctions, South Africa passed the Medicines and Related Substances Act of 1997. This Act authorized parallel importing and compulsory licensing. ${ }^{483}$ The health minister was vested with powers to compulsorily license patents in a public health crisis. In 1998, the United States denied South Africa the permission to export under the generalized system of preference scheme (GSP) unless the 1997 act was amended. ${ }^{484}$ In April of 1999 the United States included South Africa in the annual "watch list."

In July 1999, a team from the United States visited Cape Town to discuss TRIPS compliance. ${ }^{485}$ At the time, one in every five South Africans was infected with AIDS ${ }^{486}$ and South Africa accounted for a total of 26 million of the world's 36 million HIV affected patients. ${ }^{487}$ In seven countries in southern Africa, at least $20 \%$ of adults had HIV. Botswana accounted for the highest percentage of the disease with $35.8 \%$ infected adults. ${ }^{488}$ The extent of AIDS forced the United States to amend its policy within a month. President Clinton "issued an executive order to promote access to HIV/AIDS medicines in South Africa." $" 489$ By December of 1999, the United States trade office issued a statement extending the South African policy to all poor countries. ${ }^{490}$ Thus, the United States put itself in a defensive position, which set off a chain reaction. Developing countries accused the United States of forcing inhumane policies. AIDS activists and public health groups severely condemned the United States.

\section{b. Thailand}

Thailand reported its first case of AIDS in 1984. Within ten years, a million people were infected. ${ }^{491}$ The 1979 patent legislation did not provide patent protection to drugs and thus facilitated generic drugs. Thailand was included in the United States "watch list" in $1989 .{ }^{492}$ The United States

482. Id.

483. Id.

484. Id. Pretoria sought additional benefits under the generalized system of preference scheme. This scheme allows poor countries to export products to the U.S. at reduced duties. Id.

485. Id.

486. Id.

487. Id.

488. Id.

489. Rosalyn S. Park, The International Drug Industry: What the Future Holds for South Africa's HIV/AIDS Patients, 11 MINN. J. GLOBAL TRADE 125, 138 (2002).

490. Id.

491. Rosemary Sweeney, The U.S. Push for Worldwide Patents Protection for Drugs Meets the AIDS Crisis in Thailand: A Devastating Collision, 9 PAC. RIM L. \& POL'Y J. 445, 446 (2000).

492. Id. 
threatened to impose sanctions unless amendments were introduced before November of $1989 .{ }^{493}$ By 1991, Thailand was moved to the "priority watch list"-a status the United States imposed on countries grossly violating intellectual property rights. This pressure forced Thailand to amend its patent legislation in $1992 .^{494}$ The 1992 patent act created the Pharmaceutical Patent Board ("Board") with compulsory licensing powers in a public health crisis. The Board had the power to control prices by seeking pricing and cost information of drugs. The United States was dissatisfied with the amendments and continued to place Thailand in the "priority watch list." Thailand feared economic retaliation since America is Thailand's largest export market. ${ }^{495}$ In 1997, Thailand suffered a severe economic crisis resulting in additional reliance on American exports. America used the opportunity to negotiate patent amendments. TRIPS compliant amendments were made to the Thai patent legislation in 1999. The patent friendly amendments, however, resulted in a public health crisis. The cost of drugs increased by several fold and access to critical drugs were denied to poor people. By 2000 about $3 \%$ of the population was reported to have AIDS, which became the leading cause of death among Thais. ${ }^{496}$

America had to reconsider its policy again. By January 27, 2000, a United States trade representative office indicated that, "[i]f the Thai government determines that issuing a compulsory license is required to address its health care crisis, the US will raise no objections, provided the compulsory license is issued in a manner fully consistent with the WTO TRIPS Agreement." ${ }^{, 497}$

\section{c. Brazil}

The precedent established by South Africa and Thailand aided Brazil. Brazil complied with TRIPS by amending its patent law in $1996 .{ }^{498}$ The amended act vested the power to compulsorily license patented product not worked locally. ${ }^{499}$ The United States argued that the local manufacturing requirement in Brazil's amended patent law violated TRIPS. Therefore, the

493. Id

494. Id.

495. Id.

496. Id.

497. Susannah Markandya, Timeline of Trade Disputes Involving Thailand and Access to Medicines (July 23, 2001), at http://www.cptech.org/ip/health/c/thailand/thailand.html.

498. Brazil Industrial Property-Law No. 9279 of May 14, 1996.

499. Id. 
United States requested WTO to establish a dispute resolution panel and review the dispute. ${ }^{500}$

Meanwhile, spending $\$ 303$ million per annum on a single antiretroviral drug pushed Brazil to its economic limit. Brazilian officials launched a vigorous campaign against the United States position. Brazil requested Roche, to reduce the cost of the antiretroviral drug. However, Roche, refused to even consider anything more than a $30 \%$ reduction in price. ${ }^{501}$ Unable to face the expenses, Brazil openly renounced drug patents in 2001 and challenged the developed nations by threatening to compulsorily license antiretroviral drugs. ${ }^{502}$ Roche negotiated a $70 \%$ cost reduction to continue supplying the drug. ${ }^{503}$ The Office of the United States Trade Representative issued a statement pledging his cooperation to combat AIDS, ${ }^{504}$ and the United States dropped claims against Brazil in the WTO. ${ }^{505}$

\section{d. India}

India passed the first patent amendment in 1999 in response to American pressure. India neither implemented the first amendment to the fullest nor passed the more crucial second amendment. ${ }^{506}$ In the meantime, events in South Africa and Brazil increased the demand for generic drugs. After being on the defensive for not amending patent laws, India gained an offensive position and pointed to American insensitivity to poverty. India assumed the lead position in the Qatar meeting of the WTO and gained concessions for developing nations. ${ }^{507}$

500. Press Release, U.S. Department of State, U.S., Brazil Withdraw HIV/AIDS dispute from WTO Litigation (June 25, 2001), available at http://usinfo.state.gov/topical/econ/ group8/summit01/wwwh01065212.html (last visited Mar. 1, 2003). at $\mathrm{C} 1$.

501. Jennifer Rich, Roche Reaches Accord on Drug with Brazil, N.Y. TimES, Sept. 1, 2001,

502. Id.

503. Id.; see also Paulo Rebêlo, Brazil Targets Another AIDS Drug, WIRED NEwS, (Aug. 29, 2001), at http://www.wired.com/news/politics/0,1283,46353,00.html. See generally Roche Surprised by Authorities' Declaration, Medicine-News.COM (Aug. 24, 2001), at http://www.roche.com/med-corp-detail-2001?id=686.

504. U.S. Dep't of State, U.S., Brazil Withdraw HIV/AIDS Dispute from WTO Litigation (June 25, 2001), at http://usinfo.state.gov/topical/econ/group8/summit01/wwwh01062512.html.

505. Helene Cooper, U.S. Drops WTO Claim Against Brazilian Patent Law, WALL ST. J., June 26, 2001, at B7.

506. See supra Part III.B.

507. See supra note 477 and accompanying text. 


\section{Monetary Loss}

The loss of stature discussed above was not the only loss for the United States. The American government ${ }^{508}$ and the drug industry lost monetarily. The drug industry granted concessions in existing markets, lost potential density markets and the lost future deals until 2016 , as detailed below. The faulty strategy of the drug industry also became a blessing to the genericdrug industry.

\section{a. Drug Industry Loss In Existing Markets}

In South Africa, Bristol Myers reduced prices of two HIV medicines from $\$ 3589$ per annum to $\$ 54 .^{509}$ Merck dropped the price of two antiretroviral drugs, Crixivan (indinavir sulfate) and Stocrin (efavirenz), from $\$ 6000$ to $\$ 600$ and $\$ 500$ respectively. ${ }^{510}$ Glaxo SmithKline PLC offered Combivir at $\$ 730$ from $\$ 6289 .{ }^{511}$ Roche Holdings AG lowered prices by more than $90 \%$ of the original cost. ${ }^{512}$

Roche's offer to Brazil to cut $13 \%$ of the cost of antiretroviral triggered Brazilian officials to dismiss drug patents "when companies employ[] abusive pricing policies." 513 Prompted by the threat to compulsorily license AIDS drugs, Merck slashed prices of two AIDS drugs by $65 \%$ and $59 \%$ in

508. The American government provided funding to either check epidemics or to replenish its tarnished image. For example, the United States government funded $\$ 480$ million to South Africa to contain AIDS. This sum was provided in foreign assistance. Moreover, the United States promised a sum of $\$ 200$ million to fight AIDS in Africa. The Secretary of State promised additional sums in the wake of a United Nations' estimate that a few billion dollars annually would be required. Additionally, Thailand now relies on the United States and the other developed nations to fund its AIDS program. See Michael M. Phillips, Rapt Powell Hears of AIDS Suffering, WALL ST. J. EUR., May 29, 2001, at 2; see also Bill Nichols, Africans Hold Powell To A High Standard, USA TODAY, May 29, 2001, at 6A.

509. See Sarah Bosley, Embarrassed Firms Slash AIDS Drug Prices, THE GuARDian (Mar. 12, 2001), at http://www.guardian.co.uk/aids/story/0,7369,450388,00.html; see also Charlotte Denny, A Spoonful of Sugar Will Not Help, The Guardian, (Apr. 19, 2001), at http://www.guardian.co.uk/aids/story/0,7369,475344,00.html; Gardiner Harris, AIDS Gaffes in Africa Come Back to Haunt the Drug Industry at Home, WALL St. J., Apr. 23, 2001, at Al. Interestingly, Bristol Meyers lowered its price beyond cost and Merck lowered its price cost by $55 \%$ to compete with the prices offered by an Indian drug company, Cipla Pharmaceuticals. Michael Waldholz \& Rachel Zimmerman, Bristol Myers Offers to Sell Two AIDS Drugs in Africa Below Cost, WALL ST. J., Mar. 15, 2001, at B1.

510. Bosley, supra note 509.

511. Id.

512. Id.

513. Alex Bellos, Roche Bows to Brazil on Aids Drug, THE GuARDIAN (Sept. 1, 2001), at http://www.guardian.co.uk/international/story/0,3604,545328,00.html. 
Brazil to avoid competition from generic drugs. ${ }^{514}$ This resulted in Roche cutting prices by another $40 \%$, finally selling the drug at $70 \%$ of the original cost. $^{5}$

\section{b. Drug Industry -Loss of Markets}

The strategic mistake of the business interest groups of developed nations is costly to the huge Indian market. The unrealistic pricing of imported drugs at the outset caused the development of the indigenous generic-drug industry in India. Today, the Indian generic drugs compete with American patented drugs internationally.

Foreign pharmaceutical companies had another opportunity to invest in India when the Indian government reduced drug price controls to encourage foreign investment in pharmaceuticals. Instead of realistically strategizing, drug companies like Hoechst, Glaxo, and Pfizer increased the prices for bulk drugs. People protested vigorously and took to the streets. A public interest writ was instituted in the Supreme Court of India alleging violation of constitutional rights. ${ }^{516}$ Since health care is a constitutional issue, ${ }^{517}$ the Supreme Court of India directed the government to deposit the excess profit of the drug companies amounting to $\$ 400,000$ into the Drug Prices Equalizing Account. ${ }^{518}$ In the 1993 balance sheet, Pfizer earmarked nearly $\$ 1$ million to pay back the government. ${ }^{519}$ The government terminated the plan in 1986 and restored price control. ${ }^{520}$ The big loss for the drug companies was not the minimal penalty, but the loss of an opportunity to capture the India market.

514. Melody Petersen with Jennifer L. Rich, Roche Asks for Meeting With Brazil Health Minister, N.Y. TIMES, Aug. 24, 2001, at C2.

515. Rich, supra note 501 .

516. Article 21 of the Indian Constitution provides for right to life. See supra notes 141143 and accompanying text. Several supreme court judgments have interpreted this to include the right to a healthy life. The court has held that right to a healthy life is a part of the 'basic structure' of the Constitution. Kesavananda Bharathi v. State of Kerala, A.I.R. 1973 S.C. 1461, 1463.

517. See supra note 142.

518. Amitava Guha, Price Control Of Drugs In India - An Overview, Health Libr., Jan. 2001, at http://www.healthlibrary.com/reading/rdb/july98/price.htm.

519. Id.

520. Id. 


\section{Loss From Doha}

The Declaration in Doha ("Declaration") marks a retreat for multinational drug companies. ${ }^{51}$ The WTO recognized the gravity of public health problems afflicting developing countries and granted concessions. ${ }^{522}$ The Declaration specifically dilutes the vigor of the TRIPS agreement. Clause 4 of the Declaration ${ }^{523}$ states that:

[T] he TRIPS Agreement does not and should not prevent members from taking measures to protect public health. Accordingly, while reiterating our commitment to the TRIPS Agreement, we affirm that the Agreement can and should be interpreted and implemented in a manner supportive of WTO members' right to protect public health and, in particular, to promote access to medicines for all. ${ }^{524}$

Clause 5 incorporates the right to grant compulsory licenses and the freedom to determine the grounds for granting such licenses. ${ }^{525}$

With respect to pharmaceutical products, the least-developed country members will not be obliged to implement or apply the TRIPS agreement, part II sections 5 and 7 or to enforce rights provided for under these sections until January 1, 2016. Additionally, the members can seek extensions of the transition periods provided in Article 66 (1) of the TRIPS agreement. ${ }^{526}$

Clause 6 also "recognizes that WTO members with insufficient or no manufacturing capacities in the pharmaceutical sector could face difficulties in making effective use of compulsory licensing under the TRIPS agreement." 527 Moreover, the Council for TRIPS has to provide a solution enabling generic drug industries to these members by the end of $2002 .^{528}$

The Declaration will embolden countries to challenge the drug industry if the cost of drugs becomes unaffordable. ${ }^{529}$ The wide definition of drugs in the Declaration diminishes the line between important and necessary drugs. ${ }^{530}$ Thus, even the cost of non-AIDS drugs can be challenged. The

521. Declaration on TRIPS Agreement and Public Health at Qatar, supra note 311.

522. Id.

523. Id.

524. Id.

525. Id.

526. Id.

527. Id.

528. Id.

529. Gardiner Harris \& Rachel Zimmerman, Drug Makers Say WTO Setback Will Not Have Significant Impact, WALL ST. J., Nov. 10, 2001, at A3.

530. Id. 
Declaration also creates an official exception for the operation of the generic drug industry during a patent term. ${ }^{531}$ Clause 1 recognizes the "special needs" of developing and least developed nations articulated in the preamble of the TRIPS agreement. ${ }^{532}$ Furthermore, developing nations can use the flexibility in Clause 5 to combat epidemics. The term "epidemics" is widely defined enabling developing nations to decide whether an epidemic is prevalent based on national standards. ${ }^{533}$ Developing countries can also determine which diseases and when the "identified" diseases translate into a public health crisis. ${ }^{534}$

The drug industry cannot profitably market in least-developed nations until at least 2016. ${ }^{335}$ This deprives the industry of an opportunity to effectively incorporate these nations into the product patent regime. Now the drug industry fears that consumers in developed nations will take a cue from these international incidents and demand commensurate prices. Such a move will impact the survival, ${ }^{536}$ research, and development activity of the drug industry. ${ }^{537}$

\section{Impractical Assumptions and Inadequate Alternatives}

Developed nations have mistakenly made the western model the norm to tackle unique global issues. Decades have passed since developed nations tackled issues similar to those in developing nations. Hence, developed nations lack an understanding of the fact that developing countries cannot sacrifice their ailing millions for fear of trade sanctions. In a self-absorbed momentum, developed nations dismissed the objections of developing nations and advocated the TRIPS agreement patent policy impractically. ${ }^{538}$ A realistic assessment of the issues is necessary to successfully harmonize patent policies.

Scholarly works in developed nations tend to lack depth in appreciating realities. Discussion among experts is a little stifled and reflects a tacit intellectual refusal to understand the difficulties of implementing patent

531. Id.

532. Declaration on TRIPS Agreement and Public Health at Qatar, supra note 311. Id.

533. Id. Clause 5(c) highlights that a public health crisis can result in a national emergency.

534. Id.

535. Id.

536. See sources cited supra note 232; infra note 541.

537. John Carey \& Amy Barrett, Drug Prices-What's Fair?-How Can We Encourage Research And Still Keep Prices Within Reach . . for Cipro And Beyond, Bus. WK., Dec. 10, 2001 , at 61 .

538. Id. 
policies without adequate infrastructure as discussed below. Hence, the theoretical assessment :by developed nations of the workability of the demands of the TRIPS agreement is practically flawed.

George Foster (in analyzing India) suggests that, "[d]rug consumers in India seem to be somewhat better organized and more political than their counterparts in the [United States] as they have been extremely vocal in their opposition to patent reform from the beginning and have taken part in massive protests with other anti-GATT demonstrators." 539 "This academically logical argument lacks understanding of the systems in developing countries. Poor people do not function by organization. Impoverished people with nothing to hold onto figure they lose nothing in challenging their governments. Lacking the economic power to fight in an organized manner they take to the streets. ${ }^{540}$ The best example of this is the recent behavior of people of Argentina in the wake of economic crisis. ${ }^{541}$ There was no organized effort to protest, but people facing the same difficulties united quickly. The Argentineans are by no means more organized than the Americans - they are merely more upset with their governments. Governments in developing countries are aware of this and fear the people's power rather than sanctions by GATT or the International Monetary Fund (IMF). Foster's suggestion that "[i]t is hard to imagine that the members of any ruling party would feel comfortable running the risk of incurring IMF disfavor, facing rescission of GATT benefits, and risking possible unilateral U.S. trade sanctions" lacks appreciation of functional realities. ${ }^{542}$ Although developing nations are criticized as short-sighted for daring the IMF and GATT, the failure of the IMF policy in Argentina, leading poor Argentina finally to the streets, is a lesson not to attempt uniformity in policies without accounting for diversities. ${ }^{543}$

539. Foster, supra note 232, at 309.

540. See supra notes 469-74 and accompanying text (discussing translation of discontentment in developing nations into unrest).

541. Lucia Newman, Argentina Teeters on Possible Economic Collapse, CNN.COM, Dec. 21, 2001, at World Section, at http://www.cnn.com/2001/WORLD/americas/12/20/argentina (last visited Mar. 17, 2003). Severe economic crisis in Argentina resulted in thousands of people taking to the streets of the capital. This was in protest of the government's handling of the country's worsening economic crisis forcing Mr. De la Rua, the economic minister, to resign. Id.

542. Foster, supra note 232, at 332.

543. See, Ana I. Eiras \& Bret D. Schaefer, Argentina's Economic Crisis: An 'Absence of Capitalism,' The Heritage Foundation Backgrounder (Ctr for Int'l Trade and Econ.) (Apr. 19, 2001), available at http://www.heritage.org/library/backgrounder/bg 1432.html, explaining that:

IMF shares the blame for Argentina's current malaise. The history of IMF lending to Argentina since $1983 \ldots$. . shows nearly continuous funding accompanied by policy recommendations. While some of these recommendations may have helped to liberalize the economy, most hindered 
Commentators from developed nations examining India in the post TRIPS period point to Congress (I)'s loss of majority in the upper house as a catalyst for India's failure to enact implementing legislation. ${ }^{544}$ Practically no party in India could have amended and implemented the patent legislation and hoped to survive in power. People would have rallied against any government taking away access to drugs. Foster also adds that if the Indian electorate "is not in the midst of a financial crisis . . . [it] is much more likely to support a nationalist party known for its anti-Western rhetoric than is an electorate going to the polls during such a crisis." ${ }^{, 545}$ In reality, most developing countries are amidst financial crisis as can be seen in their economies. ${ }^{346}$ Electorates in developing countries care most for their daily source of income and they perceive, however unreasonably, patent reform as an immediate threat to it. Foster's criticism that India uses poverty as an excuse without appreciating pharmaceutical patents is just as absurd as criticizing the United States government for not appreciating the Bayer patent when the Anthrax fear was at its peak. ${ }^{547}$

Another scholarly work warns that, "without adequate implementation, the United States will not attain its goal of externalizing its strong intellectual property protection through TRIPS" without establishing logistics of implementation. ${ }^{548}$ Other scholars caution additional impediments because "the GATT/TRIPS is skewed toward the developing countries .... For example, there is an emphasis on recognizing the 'special needs' of the least developed countries."549 Developed nations are likely to make a costly mistake unless they understand the systems and special needs of developing nations and work around them.

Id.

economic growth, and the reliability of IMF loans encouraged moral hazard.

After almost two decades of misguided recommendations and nearly continuous funding, the IMF's involvement in Argentina actually strengthened the power of political vested interests at the expense of economic growth.

544. Foster, supra note 232, at 319-21.

545. Id. at 322.

546. Amongst countries that have been encouraged to follow intellectual property policies and pay the cost of branded drugs are: Ethiopia, with a per capita gross domestic product (GDP) of $\$ 560$; Eritrea, with a GDP of $\$ 750$; Somalia, with a GDP of $\$ 600$; Tanzania, with a GDP of $\$ 550$; Zambia, with a GDP of $\$ 880$. Along with these African nations, there are other developing nations, such as India, with 320 million people living below the poverty index; Brazil, with 20 million impoverished AIDS patients; and several others. See Country Profiles, The Int.'l Intellectual Prop. Inst., PATENT ProteCtION AND ACCESS TO HIV/AIDS Pharmaceuticals in Sub-Saharan Africa, 59-99 (2000).

547. Id.; see also supra Part IV.F.1 (discussing United States anthrax scare).

548. Pechman, supra note 5, at 179.

549. Sabatelli, supra note 6 , at 603 . 
There is an increased need to be open to third world realities. Developed nations tend more towards unrealistic assessments merely reiterating their stance. ${ }^{550}$ Scintillating arguments vouching for the correctness of policies is inadequate for developed nations to achieve patent harmonization. Developed nations ought to encourage criticisms and be aware of undesirable effects. Knowledge of the various facets of the issues in developing nations is key to forging favorable policies.

\section{Limiting Alternatives}

Assuming that developing nations refuse to fall within the patent regime, the developed world is left with the singular alternative of pressuring countries by creating the fear of trade sanctions. Theoretically, this fear makes a formidable argument. ${ }^{551}$ In reality, "the world lacks institutions capable of imposing their decisions on sovereign national governments." 552 In the face of a national calamity and local agitation, world bodies can do very little to restore unfriendly international policies. Eventually, international institutions may at the most "authorize the use of forcemilitary or economic - to coerce national compliance" with their policies. ${ }^{553}$ "At best, military threats and economic sanctions are marginally effective at influencing domestic policies .... Even the [WTO] and its elaborate Dispute Settlement Understanding (DSU) has not altered this basic structure." 554 The established international obligations of the WTO may "authorize retaliation or [penalties] for violations," 555 but the WTO cannot execute demands for payment of penalties and the "existing international mechanisms to enforce such obligations may prove ineffective." 556 "[T]he WTO has no authority or mechanism to impose the requirements of [the dispute settlement] reports within non-compliant member states." 557 For example, the WTO could not force India to pass the Patents Amendment Bill nor satisfactorily implement the first amendment. ${ }^{558}$ The world institutions can do very little amidst a public health crisis like in South

550. For example, Foster's work was awarded the prestigious Benjamin Aaron award for best comment published in a UCLA journal in 1997-98. Foster, supra note 232, at 230.

551. Joshua D. Samoff, Sarnoff Response to Caldwell: A "World Law" Without Agreement on Environmental Values?, 10 COLO. J. INT'L ENVTL. L. \& POL'Y 251, 253 (1999).

552. Id.

553. Id.

554. Id.

555. Id at 253-54.

556. Id. at 254 .

557. Id.

558 See supra Part III.B. 
Africa, or local unrest like in Argentina, ${ }^{559}$ or even isolation like Afghanistan's erstwhile Taliban.

\section{The Terror Angle}

Before the war on terrorism began, developed nations needed virtually nothing from developing nations, while the economies of developing nations depended heavily on trade with developed nations. The war on terrorism has forced a symbiotic relationship between the developed and the developing nations. ${ }^{560}$ Developed nations need the help of developing countries like India, Pakistan, and even underdeveloped nations like Somalia to fight the war on terror successfully. This has added one important limitation to the alternatives available for developed nations. Developed nations can no longer wield the trade sanction stick as effectively. This exemplifies the need of the developed nations to understand third world realities in policy making.

Therefore, the emphasis has moved towards strategizing practically. For the first time, developing nations seem to have the luxury of bargaining power. The developing nations are looking at this as a great opportunity to prosper economically. This leaves the developed nations with the need to avoid hostility with developing nations. This adds pressure to the developed nations to ensure that policies propounded for developing nations are practical enough to lead to economic solutions.

\section{Future Strategies}

Unlike the popular theory, the divide between developing and developed nations is hardly ideological. Every country wants to improve economically. The developing countries are no exception. Developing countries would never want to shun the gains of capitalism and the infrastructure of the developed nations. However, realities in developing countries demand trading of social justice for economic needs. The issues underlining the developing nations are unique and must be addressed for world progress.

559. See supra notes 541-543 and accompanying text; see also Matt Moffett \& Michelle Wallin, Argentina Picks Peronist Duhalde as Fifth President in Two Weeks, WALL St. J., Jan. 2, 2002 , at A3.

560. See supra Part IV.I.1. For example, in an effort to keep poorer nations on their side in the war on terrorism, United States and European negotiators made big concessions reflecting the new realties of the post September 11,2001 world. Id. 
Developed nations need to efficiently balance policies to maintain their stature internationally. Global intellectual property should accommodate individual nations to create a level playing field. ${ }^{561}$ Developing countries have to be inducted beneficially into the trade and intellectual property systems through economic development. ${ }^{562}$ Economic development can be facilitated by addressing individual concerns of nations ranging from prosperity of the nation and density of disease, to the accessibility of infrastructure to the people. The Convention on Biological Diversity ${ }^{563}$ may be used as a mechanism to transfer technology for economic development. ${ }^{564}$ It can lead to metamorphosis of the legal, economic, and political structures of developing countries, which is vital to economic growth. ${ }^{565}$ Economic development will boost industries to seek intellectual property protection.

The embracing of copyright laws by the Indian computer industry is an example. Once the Indian computer industry realized its global competence, it canvassed the government for intellectual property legislation. ${ }^{566}$ In time, the drug industries will also follow the path of the computer industry. The development of an indigenous drug industry stimulated the reduction of price control in India, proving that restrictions will be reduced if core issues are tackled. Even multi-national drug industries could have prospered in developing countries by negotiating a fair price at the outset. A practical understanding of both the per capita income and the lack of insurance ${ }^{567}$ would have enabled the chartering of a viable strategy. A strategy of improving manufacturing and distribution

561. Gail Wilensky, who ran the Medicare system in the last Bush administration and an adviser to a number of Republican Members of the Congress, suggests rolling back patent protection as a free market alternative to price controls. Replying to the outcry on drug prices, she responded that the United States needs to "rethink whether we are in exactly the right balance point on intellectual property rights." Alan Murray, Drug Makers' Battle is One Over Ideas, WALL ST. J., Mar. 19, 2001, at A1.

562. Gana, supra note 13 , at 737-38.

563. UN Conf. on Env't \& Dev.: Convention on Biological Diversity, June 5, 1992, 31 I.L.M. 818 (1992).

564. Srividhya Ragavan, The Global South as the Key to Biodiversity and Biotechnology-A Reply to Professor Chen, 32 ENVIR. L. REP. 10,358, 10,359 (2001); see also Srividhya Ragavan, Protection Of Traditional Knowledge, 2 MINN. INTELL. ProP. REV. 1, 32-35 (2001).

565. Ragavan, Global South, supra note 564, at 10,359.

566. A.K. Chakravarti, Protecting Proprietary and Security Rights in Cyberspace: Initiatives in India, Indian Department of Elections, at http://www.unesco.org/webworld/ infoethics-2leng/papers/paper15.rtf (last visited Mar. 17, 2003). The computer industry in India aided the government in amending the copyright legislation to suit industrial needs. Id.

567. See generally, Heinz Redwood, NEW HORIzONS IN INDIA: THE CONSEQUENCES OF Pharmaceutical Patent Protection 17 (1994). 
networks would have contributed to the economy and probably generated acceptance by the people.

Developed nations should grant concessions to poor countries when bargaining for patent protection when realistically possible. Developed nations have a stronger bargaining position for thorough implementation of patent laws in other areas, provided the pharmaceuticals issue is realistically assessed. The alternative of introducing developing countries into the intellectual property regime on a subject matter basis should be examined. ${ }^{568}$

\section{CONCLUSION}

Developed nations need to understand that polices advocated by them should enable third-world governments to confidently argue the cases of international advocates with people. This will not happen unless international policies are poised to secure national benefits. Otherwise, it is impossible for governments, however pressured, to successfully implement a policy along the lines of the current TRIPS patent policy. Developed nations need to carefully shun policies with potential to backfire on them. The failure of drug patent policy necessitates a greater appreciation of relevant issues. There is a heightened need to balance uniformity in policies with individual countries' needs. Equality amongst unequals cannot be achieved with the "stroke of a policy." Patent policies should trace a futuristic path, lead nations towards a trade-oriented system, and not create discontentment. The post-World War globe makes it easier for discontentment in obscure corners of the world to affect the rest of the world in ways that sets the clock back by several decades. Hence, policies need to cater to global realities. An unwise policy can unnecessarily upset the trade regime that the developed nations have meticulously perfected.

568. See Chakravarthi Ragavan, UNCTAD Warns of Political Backlash to Globalization, TWN Third World Network, at http://www.twnside.org.sg/title/ack-cn.htm (last visited Feb. 28, 2002). 
